\title{
Reactive nitrogen, ozone and ozone production in the Arctic troposphere and the impact of stratosphere-troposphere exchange
}

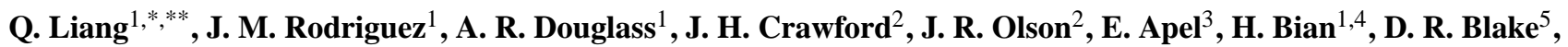 \\ W. Brune ${ }^{6}$, M. Chin ${ }^{1}$, P. R. Colarco ${ }^{1}$, A. da Silva ${ }^{7}$, G. S. Diskin ${ }^{2}$, B. N. Duncan ${ }^{1}$, L. G. Huey ${ }^{8}$, D. J. Knapp ${ }^{3}$, \\ D. D. Montzka ${ }^{3}$, J. E. Nielsen ${ }^{7,9}$, S. Pawson ${ }^{7}$, D. D. Riemer ${ }^{3}$, A. J. Weinheimer ${ }^{3}$, and A. Wisthaler ${ }^{10}$ \\ ${ }^{1}$ NASA Goddard Space Flight Center, Atmospheric Chemistry and Dynamics Branch, Code 613.3, Greenbelt, \\ MD 20771, USA \\ ${ }^{2}$ NASA Langley Research Center, Hampton, VA 23681-2199, USA \\ ${ }^{3}$ National Center for Atmospheric Research, 1850 Table Mesa Dr., Boulder, CO 80307, USA \\ ${ }^{4}$ Joint Center for Environmental Technology, University of Maryland, Baltimore County, Maryland, USA \\ ${ }^{5}$ University of California, 570 Rowland Hall, Irvine, CA 92697, USA \\ ${ }^{6}$ Department of Meteorology, Pennsylvania State University, University Park, PA 16802, USA \\ ${ }^{7}$ NASA Goddard Space Flight Center, Global Modeling and Assimilation Office, Code 610.1, Greenbelt, MD 20771, USA \\ ${ }^{8}$ School of Earth and Atmospheric Sciences, Georgia Institute of Technology, Atlanta, GA 30332, USA \\ ${ }^{9}$ Science Systems and Applications Inc., Lanham, Maryland, USA \\ ${ }^{10}$ Institute for Ion Physics \& Applied Physics, University of Innsbruck, 6020 Innsbruck, Austria \\ * formerly at: Goddard Earth Sciences \& Technology Center, University of Maryland, Baltimore County, Maryland, USA \\ ** currently at: Universities Space Research Association, GESTAR, Columbia, Maryland, USA
}

Received: 23 March 2011 - Published in Atmos. Chem. Phys. Discuss.: 6 April 2011

Revised: 21 October 2011 - Accepted: 9 December 2011 - Published: 21 December 2011

\begin{abstract}
We use aircraft observations obtained during the Arctic Research of the Composition of the Troposphere from Aircraft and Satellites (ARCTAS) mission to examine the distributions and source attributions of $\mathrm{O}_{3}$ and $\mathrm{NO}_{\mathrm{y}}$ in the Arctic and sub-Arctic region. Using a number of marker tracers, we distinguish various air masses from the background troposphere and examine their contributions to $\mathrm{NO}_{\mathrm{x}}$, $\mathrm{O}_{3}$, and $\mathrm{O}_{3}$ production in the Arctic troposphere. The background Arctic troposphere has a mean $\mathrm{O}_{3}$ of $\sim 60 \mathrm{ppbv}$ and $\mathrm{NO}_{\mathrm{x}}$ of $\sim 25$ pptv throughout spring and summer with $\mathrm{CO}$ decreasing from $\sim 145 \mathrm{ppbv}$ in spring to $\sim 100 \mathrm{ppbv}$ in summer. These observed mixing ratios are not notably different from the values measured during the 1988 ABLE-3A and the 2002 TOPSE field campaigns despite the significant changes in emissions and stratospheric ozone layer in the past two decades that influence Arctic tropospheric composition. Air masses associated with stratosphere-troposphere exchange are present throughout the mid and upper troposphere during spring and summer. These air masses, with mean $\mathrm{O}_{3}$ concentrations of 140-160 ppbv, are significant direct sources of $\mathrm{O}_{3}$ in the Arctic troposphere. In addition, air of stratospheric
\end{abstract}

origin displays net $\mathrm{O}_{3}$ formation in the Arctic due to its sustainable, high $\mathrm{NO}_{\mathrm{x}}(75 \mathrm{pptv}$ in spring and $110 \mathrm{pptv}$ in summer) and $\mathrm{NO}_{\mathrm{y}}(\sim 800 \mathrm{pptv}$ in spring and $\sim 1100$ pptv in summer). The air masses influenced by the stratosphere sampled during ARCTAS-B also show conversion of $\mathrm{HNO}_{3}$ to PAN. This active production of PAN is the result of increased degradation of ethane in the stratosphere-troposphere mixed air mass to form $\mathrm{CH}_{3} \mathrm{CHO}$, followed by subsequent formation of PAN under high $\mathrm{NO}_{\mathrm{x}}$ conditions. These findings imply that an adequate representation of stratospheric $\mathrm{NO}_{\mathrm{y}}$ input, in addition to stratospheric $\mathrm{O}_{3}$ influx, is essential to accurately simulate tropospheric Arctic $\mathrm{O}_{3}, \mathrm{NO}_{\mathrm{x}}$ and PAN in chemistry transport models. Plumes influenced by recent anthropogenic and biomass burning emissions observed during ARCTAS show highly elevated levels of hydrocarbons and $\mathrm{NO}_{\mathrm{y}}$ (mostly in the form of $\mathrm{NO}_{\mathrm{x}}$ and PAN), but do not contain $\mathrm{O}_{3}$ higher than that in the Arctic tropospheric background except some aged biomass burning plumes sampled during spring. Convection and/or lightning influences are negligible sources of $\mathrm{O}_{3}$ in the Arctic troposphere but can have significant impacts in the upper troposphere in the continental sub-Arctic during summer.

\section{Correspondence to: Q. Liang}

(qing.liang@nasa.gov) 


\section{Introduction}

Tropospheric ozone $\left(\mathrm{O}_{3}\right)$ is important as it affects air quality and is a greenhouse gas. The Arctic has been warming at twice the global average rate over the past century (IPCC, 2007). While increases in long-lived greenhouse gases dominate Arctic warming, $\mathrm{O}_{3}$ and other short-lived pollutants (e.g., aerosols) could also play an important role (Law and Stohl, 2007; Shindell, 2007; Quinn et al., 2008). Changes in local tropospheric $\mathrm{O}_{3}$ affect the Arctic climate by altering local radiation fluxes with maximum impact near the tropopause (Hansen et al., 1997). A recent modeling study suggests that an increase in tropospheric $\mathrm{O}_{3}$, caused by increases in anthropogenic emissions, could have contributed about $0.3^{\circ} \mathrm{C}$ annually to the 20th-century Arctic surface warming and about $0.4^{\circ} \mathrm{C}-0.5^{\circ} \mathrm{C}$ during winter and spring (Shindell et al., 2006). The impact of possible increases in boreal forest fire emissions and changes in stratospheric $\mathrm{O}_{3}$ flux to the troposphere on Arctic surface warming are not yet well quantified.

Ozone is produced locally in the Arctic troposphere from its precursors (i.e., carbon monoxide (CO), hydrocarbons, nitrogen oxides $\left(\mathrm{NO}_{\mathrm{x}}\right)$ ) emitted from anthropogenic and biomass burning sources in adjacent continents (e.g., Penkett and Brice, 1986; Wofsy et al., 1992; Beine et al., 1997). Additional potential sources of $\mathrm{O}_{3}$ in the Arctic troposphere include transport of $\mathrm{O}_{3}$ from lower latitudes (Shindell et al., 2008) as well as transport from the stratosphere (Dibb et al., 2003; Allen et al., 2003). Stratospheric air contains high $\mathrm{NO}_{\mathrm{x}}$ and nitric acid $\left(\mathrm{HNO}_{3}\right)$ and is also an important source of $\mathrm{NO}_{x}$ when injected into the Arctic troposphere (Wofsy et al., 1992; Levy et al., 1999; Law and Stohl, 2007; Liang et al., 2009). $\mathrm{NO}_{\mathrm{x}}$ of stratospheric origin is the driving mechanism that leads to enhanced $\mathrm{O}_{3}$ production in the Arctic upper troposphere (Liang et al., 2009). A better quantification of the contribution of various anthropogenic and natural sources to $\mathrm{O}_{3}$ in the Arctic is important for understanding the temporal variation and radiative impact of $\mathrm{O}_{3}$, and how Arctic $\mathrm{O}_{3}$ may change as climate warms and the stratospheric $\mathrm{O}_{3}$ layer recovers. The NASA Arctic Research of the Composition of the Troposphere from Aircraft and Satellites (ARCTAS) mission was conducted in April and JuneJuly 2008 (Jacob et al., 2010). Its goal was to better understand the factors driving changes in Arctic atmospheric composition and climate. The extensive and detailed measurements of $\mathrm{O}_{3}$ and reactive nitrogen $\left(\mathrm{NO}_{\mathrm{y}}\right)$ species provide a great opportunity to examine the photochemistry of $\mathrm{O}_{3}$ and $\mathrm{NO}_{\mathrm{x}}$, and their sources in the Arctic. In this paper, we will use observations obtained onboard the NASA DC- 8 aircraft during ARCTAS to examine $\mathrm{O}_{3}$ and $\mathrm{NO}_{\mathrm{y}}$ in the Arctic and sub-Arctic region and their source attributions. Section 2 describes the observations used in this study. We use a set of marker tracers to identify various air masses sampled during ARCTAS and examine their chemical composition, as described in Sect. 3. $\mathrm{NO}_{\mathrm{x}}$ plays a determinative role in $\mathrm{O}_{3}$
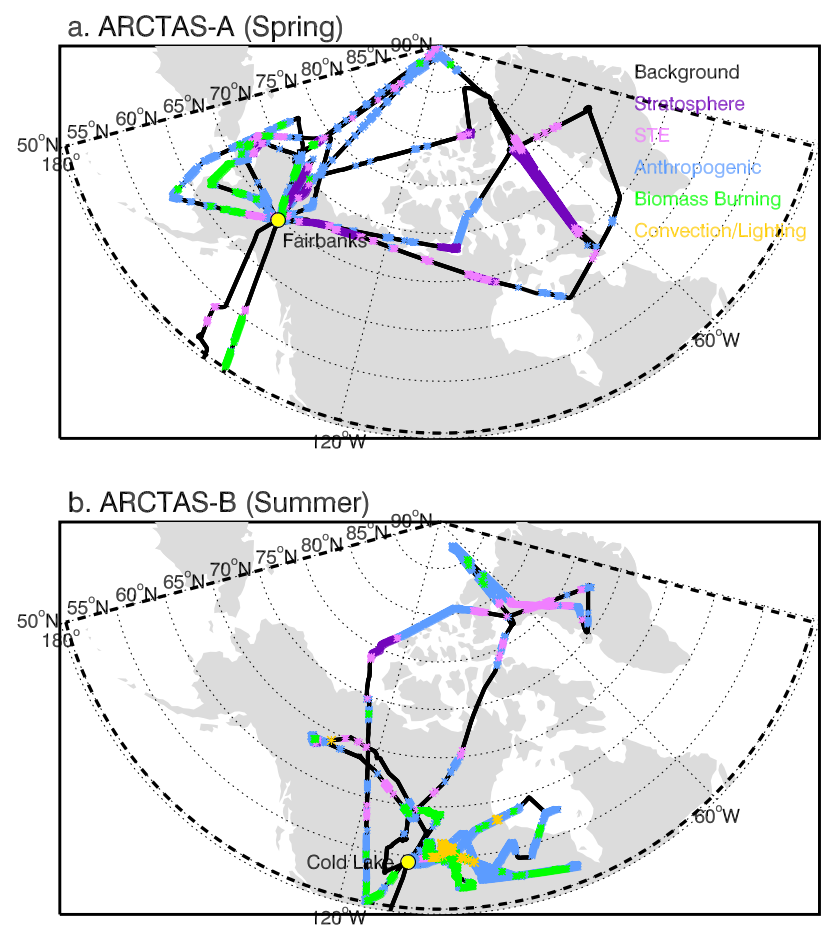

Fig. 1. Flight tracks (black solid lines) of the NASA DC-8 aircraft for (a) ARCTAS-A and (b) ARCTAS-B. For this study, we only use measurements obtained north of $50^{\circ} \mathrm{N}$. The color symbols indicate the location of various air masses sampled during ARCTAS. Tracks not marked with color symbols indicate background atmosphere.

production in the troposphere. Therefore to better understand which sources contribute to $\mathrm{O}_{3}$ in the Arctic troposphere, it is important to understand sources of $\mathrm{NO}_{\mathrm{x}}$ and the long-lived reservoir species of $\mathrm{NO}_{\mathrm{x}}$, i.e., $\mathrm{HNO}_{3}$ and peroxyacetyl nitrate (PAN). We examine $\mathrm{NO}_{\mathrm{y}}$ and its partitioning in various air masses in Sect. 4, followed by an analysis of $\mathrm{O}_{3}, \mathrm{O}_{3}$ production and its dependence on $\mathrm{NO}_{\mathrm{x}}$ and $\mathrm{HO}_{\mathrm{x}}\left(\mathrm{OH}+\mathrm{HO}_{2}\right)$ levels within individual air masses sampled during ARCTAS (Sect. 5). Conclusions are presented in Sect. 6.

\section{Observations and model}

The NASA ARCTAS mission had two phases. The spring deployment (ARCTAS-A), based in Fairbanks Alaska, involved nine flights by the NASA DC-8 aircraft between 1 April and 21 April 2008. The summer deployment (ARCTAS-B) took place between 26 June and 14 July 2008 (nine flights) and was operated from a base in Cold Lake, Canada. Figure 1 shows the geographical distribution of flight tracks of the DC-8 aircraft during ARCTAS. Here we use measurements obtained north of $50^{\circ} \mathrm{N}$. During the spring phase, the majority of the measurements were collected between $60^{\circ} \mathrm{N}-90^{\circ} \mathrm{N}$. Measurements made during the summer phase were mainly in the sub-Arctic between $50^{\circ} \mathrm{N}-70^{\circ} \mathrm{N}$. 
Table 1. Summary of ARCTAS observations used in this study.

\begin{tabular}{lll}
\hline Species & Instrument \& Methods & Reference \\
\hline $\mathrm{CO}$ & Tunable Diode Laser Absorption Spectroscopy (TDLAS) & Diskin et al. (2002) \\
$\mathrm{O}_{3}, \mathrm{NO}, \mathrm{NO}_{2}, \mathrm{NO}_{\mathrm{y}}^{*}$ & Chemiluminescence & Weinheimer et al. (1994) \\
$\mathrm{HNO}_{3}$ & Chemical Ionization Mass Spectrometry (CIMS) & Crounse et al (2006) \\
$\mathrm{PAN}$ & Chemical Ionization Mass Spectrometry (CIMS) & Slusher et al. (2004) \\
$\mathrm{Alkyl} \mathrm{nitrates}$ & Thermal-Dissociation Laser Induced Fluorescence (TD-LIF) & Cleary et al. (2002) \\
$\mathrm{OH}, \mathrm{HO}_{2}^{*}$ & Laser Induced Fluorescence (LIF) & Brune et al. (1999) \\
$\mathrm{CH}_{3} \mathrm{CN}^{* *}$ & Proton Transfer Reaction - Mass Spectrometry (PTR-MS) & Wisthaler et al (2002) \\
& Gas Chromatography - Mass Spectrometry (GC-MS) & Apel et al. (2003) \\
$\mathrm{CFC}-113, \mathrm{C}_{2} \mathrm{H}_{6}$ & Whole Air Sampler - Gas Chromatography (WAS-GC) & Blake et al. (2003) \\
\hline
\end{tabular}

* Multiple sets of measurements were available for several species used in this study, i.e., $\mathrm{NO}_{2}, \mathrm{OH}, \mathrm{HO}_{2}, \mathrm{HNO}_{3}$. The different measurements broadly agree with each other and the choice of measurements does not affect the conclusion of this study. ${ }^{* *}$ Two sets of measurements were available for $\mathrm{CH}_{3} \mathrm{CN}$ : (i) the PTR-MS measurement of $\mathrm{CH}_{3} \mathrm{CN}$ is available every 8-s and 60-s, respectively, and (ii) the GC-MS measurements available every 120 -s. In general, we use $\mathrm{CH}_{3} \mathrm{CN}$ measured by PTR-MS. During time periods when there are no available PTR-MS measurements, we use the GC-MS measurements whenever possible.

Observations obtained onboard the DC-8 aircraft include $\mathrm{O}_{3}, \mathrm{HO}_{\mathrm{x}}, \mathrm{NO}_{\mathrm{x}}$, as well as $\mathrm{NO}_{\mathrm{x}}$ reservoir species, hydrocarbons, halocarbons, aerosols (Jacob et al., 2010). Segregation between various air masses relies on the availability of simultaneous measurements of the marker tracers, e.g., $\mathrm{CO}$ for combustion plumes, acetonitrile $\left(\mathrm{CH}_{3} \mathrm{CN}\right)$ for biomass burning and chloroflurocarbons (CFCs) for stratospheric air. A detailed list of the species used in this study and the associated instrument specifications is presented in Table 1. Multiple merge files (1-s, 10-s, 60-s) were created for the ARCTAS measurements. Here, we rely on the 60 -s merge. Although many species are available at higher frequency, measurements crucial to this analysis, i.e., halocarbons, from the Whole Air Sampler - Gas Chromatography, were only obtained every 160 -s.

We also use results calculated by the NASA Langley box model (Olson et al., 2004) constrained by chemical and physical parameters measured by the DC- 8 aircraft. Observed $\mathrm{O}_{3}, \mathrm{CO}, \mathrm{NO}$, temperature, $\mathrm{J}\left(\mathrm{NO}_{2}\right)$ and $\mathrm{J}\left(\mathrm{O}_{3}\right)$ from the 60-s merge were used as model input. In addition, model calculations have been constrained by observed values of many trace gases, including $\mathrm{H}_{2} \mathrm{O}_{2}, \mathrm{CH}_{3} \mathrm{OOH}, \mathrm{HNO}_{3}$, PAN, acetone, MEK, methanol, and ethanol when possible.

\section{Air masses observed during ARCTAS}

\subsection{Air sampled during ARCTAS}

While airborne field missions provide an extensive set of trace gas measurements over vast spatial regions, the flight plans are usually designed to target pollution plumes and thus biased towards these plumes. Using $\mathrm{CO}$, a commonly used tracer for combustion and atmospheric transport, we analyze the representativeness of the ARCTAS sampling to the general characteristics of the Arctic troposphere.
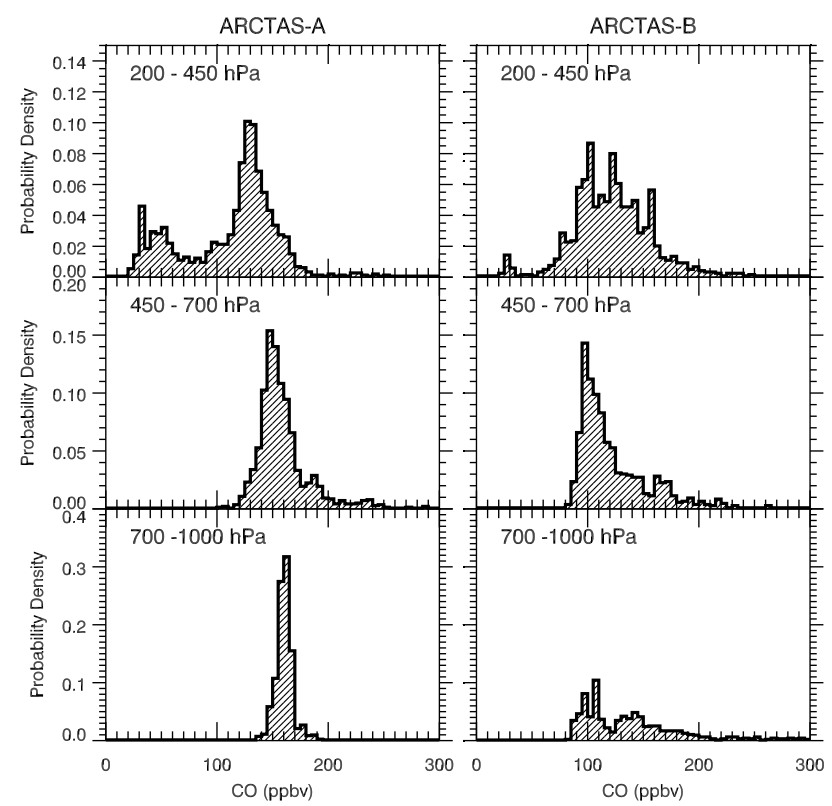

Fig. 2. The probability distribution function (PDF) of observed CO along DC-8 flight tracks for ARCTAS-A (left column) and ARCTAS-B (right column).

We analyze the probability density function (PDF) of $\mathrm{CO}$ observed during ARCTAS-A (Fig. 2). The PDF of CO displays a unimodal distribution in the lower and mid troposphere during spring with peaks at $160 \mathrm{ppbv}$ and $145 \mathrm{ppbv}$, respectively, implying a relatively well-mixed Arctic atmosphere. In the upper troposphere/lower stratosphere (UT/LS), the distribution is bimodal, with one peak at $125 \mathrm{ppbv}$ and a secondary peak at $\sim 50 \mathrm{ppbv}$ representing tropospheric and stratospheric air masses, respectively. The PDF during ARCTAS-B (Fig. 2) displays multiple peaks in the troposphere. The primary peak around $100 \mathrm{ppbv}$ 
Table 2. Air mass characterization criteria.

\begin{tabular}{|c|c|c|}
\hline \multirow[t]{2}{*}{ Air mass type } & \multicolumn{2}{|c|}{ Criteria } \\
\hline & ARCTAS-A & ARCTAS-B \\
\hline Stratospheric air & $\begin{array}{l}\mathrm{O}_{3}>100 \mathrm{ppbv} \\
\mathrm{CFC}-113<78^{\mathrm{a}} \mathrm{pptv} \\
\mathrm{CO}<80^{\mathrm{b}} \mathrm{ppbv}\end{array}$ & $\begin{array}{l}\mathrm{O}_{3}>100 \mathrm{ppbv} \\
\mathrm{CFC}-113<78^{\mathrm{a}} \mathrm{pptv} \\
\mathrm{CO}<50^{\mathrm{b}} \mathrm{ppbv}\end{array}$ \\
\hline $\begin{array}{l}\text { Stratosphere-troposphere } \\
\text { exchange }\end{array}$ & $\begin{array}{l}\mathrm{O}_{3}>100 \mathrm{ppbv} \\
\mathrm{CFC}-113<78^{\mathrm{a}} \mathrm{pptv} \\
80^{\mathrm{b}} \mathrm{ppbv} \leq \mathrm{CO}<160 \mathrm{ppbv}\end{array}$ & $\begin{array}{l}\mathrm{O}_{3}>100 \mathrm{ppbv} \\
\mathrm{CFC}-113<78^{\mathrm{a}} \mathrm{pptv} \\
50^{\mathrm{b}} \mathrm{ppbv} \leq \mathrm{CO}<120 \mathrm{ppbv}\end{array}$ \\
\hline Biomass burning & $\begin{array}{l}\mathrm{CO}>160^{\mathrm{c}} \text { ppbv; } \\
\mathrm{CH}_{3} \mathrm{CN}>145^{\mathrm{d}} \text { pptv }\end{array}$ & $\begin{array}{l}\mathrm{CO}>120^{\mathrm{c}} \text { ppbv; } \\
\mathrm{CH}_{3} \mathrm{CN}>320^{\mathrm{d}} \text { pptv }\end{array}$ \\
\hline Anthropogenic & $\begin{array}{l}\mathrm{CO}>160^{\mathrm{c}} \text { ppbv } \\
\mathrm{CH}_{3} \mathrm{CN} \leq 145^{\mathrm{d}} \text { pptv }\end{array}$ & $\begin{array}{l}\mathrm{CO}>120^{\mathrm{c}} \text { ppbv; } \\
\mathrm{CH}_{3} \mathrm{CN} \leq 320^{\mathrm{d}} \text { pptv }\end{array}$ \\
\hline Convection/Lightning & $\begin{array}{l}\mathrm{NO}_{\mathrm{x}}>100 \mathrm{pptv} \\
\mathrm{NO}_{\mathrm{x}} / \mathrm{HNO}_{3}>1.2 \mathrm{pptv}_{\mathrm{pptv}}-1\end{array}$ & $\begin{array}{l}\mathrm{NO}_{\mathrm{x}}>200 \mathrm{pptv} \\
\mathrm{NO}_{\mathrm{X}} / \mathrm{HNO}_{3}>1.2 \mathrm{pptv}_{\mathrm{pptv}}-1\end{array}$ \\
\hline
\end{tabular}

\begin{abstract}
${ }^{a}$ The 78 pptv threshold is the 25 percentile value for $\mathrm{CFC}-113$. ${ }^{\mathrm{b}}$ The $\mathrm{CO} \sim 80 \mathrm{ppbv}$ threshold level between stratospheric air and air associated with stratosphere-troposphere exchange are determined based on scattering plots of $\mathrm{CFC}-113, \mathrm{CH}_{3} \mathrm{CN}, \mathrm{SO}_{2}$ vs. CO during ARCTAS-A. The $\mathrm{CO} \sim 50$ ppbv threshold for ARCTAS-B is determined based on the scatter plots of $\mathrm{CH}_{4}, \mathrm{CO}_{2}, \mathrm{NO}_{\mathrm{y}}$ vs. $\mathrm{CO}$. ${ }^{\mathrm{c}}$ The $\mathrm{CO} \sim 160 \mathrm{ppbv}$ threshold level during ARCTAS-A for biomass burning and anthropogenic pollution is determined by the highest quartile of $\mathrm{CO}$. The $\mathrm{CO} \sim 120 \mathrm{ppbv}$ threshold during ARCTAS-B is chosen based on the PDF of $\mathrm{CO}$ (Sect. 3). ${ }^{\mathrm{d}}$ The $\mathrm{CH}_{3} \mathrm{CN} \sim 145$ pptv for ARCTAS-A and $\sim 320$ pptv for ARCTAS-B thresholds are chosen for the optimal segregation between the biomass burning and anthropogenic pollutions based on the $\mathrm{CO}_{2} / \mathrm{CO}, \mathrm{CH}_{4} / \mathrm{CO}$, and $\mathrm{C}_{2} \mathrm{H}_{6} / \mathrm{CO}$ ratio $(\mathrm{see}$ Supplement Figs. S1 and S2).
\end{abstract}

(90-120 ppbv) represents the background atmosphere and the two peaks between $120-160$ ppbv (present in the upper and lower troposphere) and $>160 \mathrm{ppbv}$ (present in the mid- and upper troposphere) are associated with either anthropogenic and/or biomass burning pollution. Acetonitrile is typically used as a tracer for biomass burning plumes (Lobert et al., 1990; Holzinger et al., 2001). The peak with $\mathrm{CO}>160$ ppbv has mean $\mathrm{CH}_{3} \mathrm{CN}$ of 520 pptv, indicating these are mostly biomass burning plumes. The other pollution peak with CO between 120-160 ppbv has relatively low level of $\mathrm{CH}_{3} \mathrm{CN}$ (200 pptv), suggesting these measurements are mostly anthropogenic pollution plumes. The fact that the combustion peaks are well separated from the background suggests these are fresh pollution plumes that have not yet mixed into the background. The extended tails of combustion plumes during summer implies that, unlike spring, the summertime sampling is highly biased towards pollution plumes.

\subsection{Air mass identification}

We use a comprehensive set of tracers to characterize air masses sampled by the DC- 8 aircraft during ARCTAS. The detailed criteria applied to define each type of air mass are listed in Table 2. Note that the thresholds of the marker gases chosen to segregate air masses of different origin are highly subjective and can vary significantly depending on season, location, and the question of interest. While we choose some criteria based on previous literature $\left(\mathrm{O}_{3}>100 \mathrm{ppbv}\right.$ for air of stratospheric origin) and the PDF distribution of
CO (Sect. 3.1) for combustion plumes, we heavily rely on tracer-tracer correlations for optimal segregation between different air masses (see Supplement, Figs. S1 and S2). We found that the $\mathrm{CO}-\mathrm{NO}_{\mathrm{y}}, \mathrm{CO}-\mathrm{CO}_{2}$ and $\mathrm{CO}-\mathrm{CH}_{4}$ correlations are particularly useful in determining the threshold levels of markers for distinguishing air in the stratosphere, air associated with recent stratosphere-troposphere-exchange (STE), biomass burning and anthropogenic plumes.

We use $\mathrm{CO}$ and $\mathrm{CH}_{3} \mathrm{CN}$ to distinguish anthropogenic and biomass burning pollution plumes. Since pollution plumes are not well separated from the background during spring (Sect. 3.1), we use the highest quartile of $\mathrm{CO}$ $(>160 \mathrm{ppbv}$ ) to define pollution plumes. Within the pollution plumes, air masses with $\mathrm{CH}_{3} \mathrm{CN}>145$ pptv are identified as biomass burning plumes and the remaining as anthropogenic pollution plumes. During summer, air masses with $\mathrm{CO}>120 \mathrm{ppbv}$ are defined as combustion plumes (Table 2). We further use $\mathrm{CO}>160 \mathrm{ppbv}$ and $\mathrm{CH}_{3} \mathrm{CN}>320 \mathrm{pptv}$ to separate biomass burning air masses from anthropogenic plumes. The thresholds of $\mathrm{CH}_{3} \mathrm{CN} \sim 145$ pptv for ARCTASA and $\sim 320$ pptv for ARCTAS-B are chosen for optimal segregation between the biomass burning and anthropogenic pollutions based on the $\mathrm{CO}_{2} / \mathrm{CO}, \mathrm{CH}_{4} / \mathrm{CO}$, and $\mathrm{C}_{2} \mathrm{H}_{6} / \mathrm{CO}$ ratios (Table 2), which differ in these two types of air masses (see Supplement, Figs. S1 and S2).

Air in the stratosphere is enriched in $\mathrm{O}_{3}$ and depleted in surface emitted pollutants such as long-lived CFCs (lifetime $\sim 45-100 \mathrm{yr}$ ) as well as short-lived CO (lifetime $\sim$ two months). Stratospheric air can enter the troposphere through 
Table 3a. Mean observed chemical composition of air masses sampled during ARCTAS- $\mathrm{A}^{\mathrm{a}}$.

\begin{tabular}{|c|c|c|c|c|c|c|c|c|}
\hline & \multicolumn{4}{|c|}{$\begin{array}{l}\text { Background } \\
2370 \mathrm{~min}\end{array}$} & \multirow{2}{*}{$\begin{array}{r}\text { Anthropogenic } \\
\text { Pollution } \\
688 \mathrm{~min} \\
(17 \%) \\
0-10 \mathrm{~km}^{\mathrm{c}}\end{array}$} & \multirow{2}{*}{$\begin{array}{r}\text { Biomass } \\
\text { Burning } \\
179 \mathrm{~min} \\
(4 \%)\end{array}$} & \multirow{2}{*}{$\begin{array}{l}\text { Stratosphere } \\
\begin{array}{r}358 \mathrm{~min} \\
(9 \%)\end{array} \\
6-12 \mathrm{~km}^{\mathrm{c}}\end{array}$} & \multirow{2}{*}{$\begin{array}{r}\text { STE } \\
125 \mathrm{~min} \\
(3 \%) \\
5-12 \mathrm{~km}^{\mathrm{c}}\end{array}$} \\
\hline & $0-12 \mathrm{~km}$ & $0-3 \mathrm{~km}$ & $3-6 \mathrm{~km}$ & $6-12 \mathrm{~km}$ & & & & \\
\hline CO (ppbv) & $144 \pm 14$ & $156 \pm 5$ & $148 \pm 9$ & $135 \pm 14$ & $172 \pm 14$ & $220 \pm 42$ & $48 \pm 14$ & $100 \pm 14$ \\
\hline $\mathrm{HO}_{2}$ (pptv) & $3.5 \pm 1.9$ & $3.4 \pm 1.9$ & $3.5 \pm 2.1$ & $3.5 \pm 1.8$ & $3.2 \pm 1.5$ & $6.4 \pm 4.1$ & $1.0 \pm 0.4$ & $1.0 \pm 0.9$ \\
\hline $\mathrm{HO}_{\mathrm{x}}$ (pptv) & $3.5 \pm 1.9$ & $3.4 \pm 2.0$ & $3.6 \pm 2.1$ & $3.6 \pm 1.8$ & $3.2 \pm 1.5$ & $6.7 \pm 4.2$ & $1.1 \pm 0.4$ & $2.0 \pm 0.9$ \\
\hline NO (pptv) & $11 \pm 28$ & $13 \pm 30$ & $9 \pm 8$ & $12 \pm 11$ & $32 \pm 372$ & $18 \pm 17$ & $\mathbf{5 0} \pm \mathbf{2 4}$ & $35 \pm 24$ \\
\hline $\mathrm{NO}_{2}$ (pptv) & $6 \pm 38$ & $3 \pm 53$ & $3 \pm 12$ & $10 \pm 16$ & $24 \pm 211$ & $33 \pm 22$ & $75 \pm 29$ & $42 \pm 17$ \\
\hline $\mathrm{NO}_{\mathrm{x}}$ (pptv) & $25 \pm 65$ & $30 \pm 85$ & $20 \pm 15$ & $30 \pm 20$ & $65 \pm 630$ & $50 \pm 40$ & $150 \pm 55$ & $80 \pm 40$ \\
\hline
\end{tabular}

${ }^{a}$ For each type of air mass we include the observed mean \pm one standard deviation. Chemical species that are significantly enhanced $(>$ mean + one standard deviation) with respect to background at the corresponding altitude are highlighted in bold. ${ }^{\mathrm{b}}$ The percentage sum of all identified air masses equals to $93 \%$ and the remaining $7 \%$ are ozone depleting events. ${ }^{c}$ The altitude span of individual air masses.

rapid synoptic eddy exchange activities, e.g., tropopause folds, or slow global-scale diabatic descent (Holton et al., 1995). The stratosphere-to-troposphere transport time ranges between a few days during rapid tropopause folding events that intrude deeply into the troposphere to the order of a month for shallow STE intrusions followed by subsequent slow diabatic descent. The difference in transport time can lead to significantly different levels of trace gases, in particular the short-lived species, such as $\mathrm{O}_{3}, \mathrm{HNO}_{3}$, and $\mathrm{Be}-7$ (Liang et al., 2009). We use the combination of a short-lived tracer, $\mathrm{O}_{3}$ (>100 ppbv), and a long-lived tracer, CFC-113 (lowest quartile, $<78$ pptv) to identify air of stratospheric origin. We choose CFC-113 over the other two more common CFCs, CFC-11 and CFC-12. This is because emissions of CFC-113 have significantly decreased since 2000 (Liang et al., 2008), due to the phase-out required by the Montreal protocol. The variation in CFC-113 is less tempered by variability due to tropospheric transport of fresh surface emissions, which can be significant, and reflects mainly the extent of mixing with stratospheric air. Therefore low CFC-113, together with high $\mathrm{O}_{3}$, is a better marker to distinguish air transported from the stratosphere. We apply an additional criterion, $\mathrm{CO}<160 \mathrm{ppbv}$ in spring $(<120 \mathrm{ppbv}$ in summer), to exclude any samples that have mixed to some extent with fresh combustion plumes. We also use $\mathrm{CO}$ levels to distinguish air that is of stratospheric origin, but has already penetrated into the troposphere through STE events ( $\mathrm{CO}>80 \mathrm{ppbv}$ and $>50 \mathrm{ppbv}$ in spring and summer, respectively), from the air that still resides in the lowermost stratosphere (Table 2). This is because air of stratospheric origin can have very different $\mathrm{NO}_{\mathrm{y}}$ partitioning and photochemical properties, e.g., $\mathrm{O}_{3}$ production rates, when it enters the troposphere and mixes with the tropospheric background, as compared to air that remains in the stratosphere. Note that the use of $\mathrm{O}_{3}>100 \mathrm{ppbv}$ for stratosphere-troposphere mixed air masses is a stringent criterion that distinguishes only the relatively fresh STE events from the background atmosphere.

The DC-8 aircraft also encountered a few deep convective events during ARCTAS-B. Air masses that have recently experienced deep convection contain enhanced levels of $\mathrm{NO}_{\mathrm{x}}$ associated with freshly-ventilated air from the boundary layer and/or lightning and are depleted in $\mathrm{HNO}_{3}$ due to scavenging (e.g., Thompson et al., 1999; Liang et al., 2007). Thus we define air as being influenced by convection/lightning when $\mathrm{NO}_{\mathrm{x}}$ exceeds $200 \mathrm{pptv}$ and the $\mathrm{NO}_{\mathrm{x}} / \mathrm{HNO}_{3}$ ratio exceeds $>1.2 \mathrm{pptvpptv}^{-1}$. During ARCTAS-A, six minutes $(<0.1 \%$ of a total $\sim 4200 \mathrm{~min}$ ) of the data contain elevated $\mathrm{NO}_{\mathrm{x}}(>100 \mathrm{pptv})$, which were of neither anthropogenic/biomass burning nor stratospheric origin. Since deep convection is not common during the high latitude spring, these measurements are most likely tied to fresh aircraft exhaust. We therefore exclude these air samples.

The remaining air masses are defined as background. Note that the DC- 8 measurements in the Arctic marine boundary layer also include a few $\mathrm{O}_{3}$ depletion events $\left(\mathrm{O}_{3}<30 \mathrm{ppbv}\right)$ during spring (Neuman et al., 2010) as well as local plumes with high $\mathrm{NO}_{\mathrm{x}}$ from coastal ship emissions in spring and Canadian power plants near Edmonton and Ft. McMurray in summer. We exclude these data in this analysis. 
Table 3b. Same as Table 3 a but for ARCTAS-B ${ }^{\mathrm{a}}$.

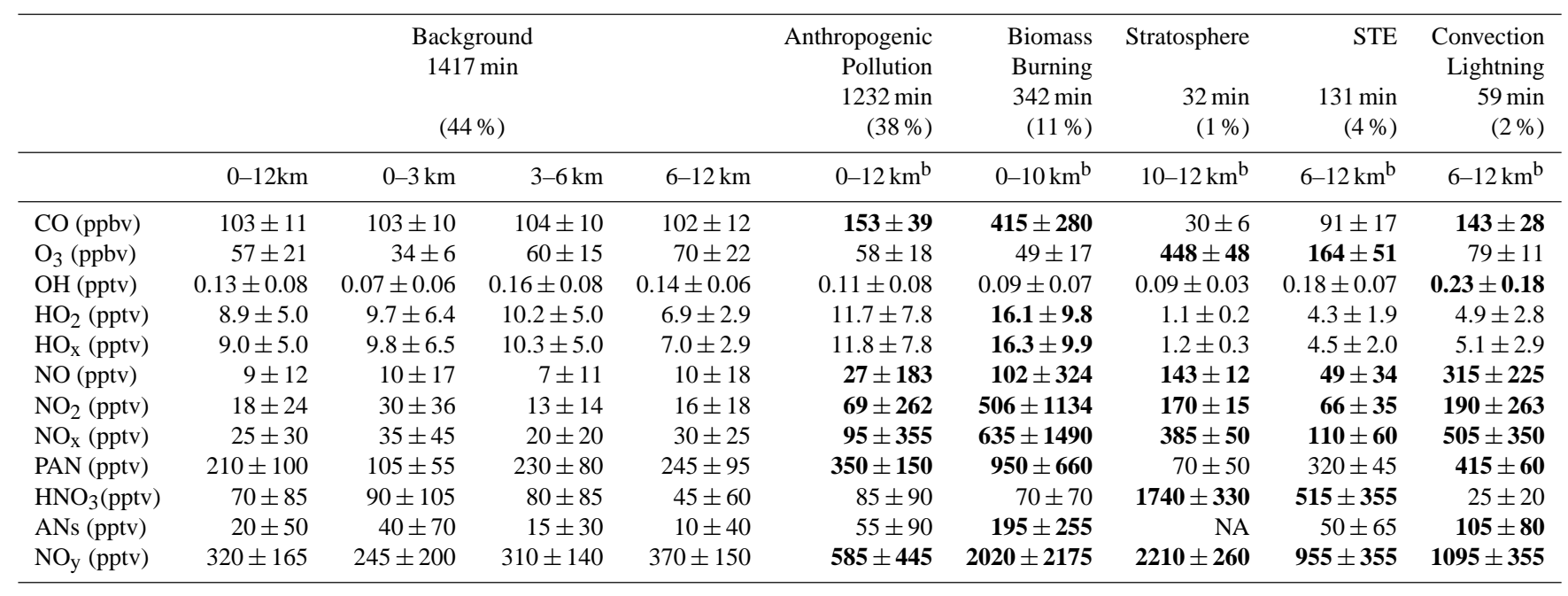

${ }^{a}$ For each type of air mass we include the observed mean \pm one standard deviation. Chemical species that are significantly enhanced $(>$ mean + one standard deviation) with respect to background at the corresponding altitude are highlighted in bold. ${ }^{\mathrm{b}}$ The altitude span of individual air masses.

\subsection{Air mass composition}

A summary of the air mass composition sampled by the DC- 8 aircraft is shown in Table 3a (for ARCTAS-A) and Table 3b (for ARCTAS-B). About $59 \%$ of the spring measurements are from the background troposphere. Pollution plumes account for $21 \%$ of the observations, $17 \%$ for anthropogenic pollution and $4 \%$ for biomass burning plumes. About $9 \%$ and $3 \%$ of the spring measurements, respectively, are of lowermost stratospheric air and air influenced by recent STE events. During ARCTAS-B, about $38 \%$ of the data are identified as fresh anthropogenic pollution and about $11 \%$ are attributed to fresh biomass burning plumes. However, as we discussed in Sect. 3.1, the ARCTAS-B measurements are biased towards combustion plumes and thus the above fractionations are not representative of the general Arctic troposphere. Stratosphere air and STE together account for $\sim 5 \%$ of the measurements. About $2 \%$ of the air sampled during ARCTAS-B was recently influenced by convection and/or lightning. Geographically, the majority of the convective and biomass burning plumes are located in the sub-Arctic between $50-70^{\circ} \mathrm{N}$ while anthropogenic and stratospheretroposphere mixed air masses are found throughout the Arctic and sub-Arctic (Fig. 1).

The background Arctic troposphere during spring has mean $\mathrm{CO}$ concentrations of $\sim 145 \mathrm{ppbv}, \mathrm{O}_{3}$ of $\sim 60 \mathrm{ppbv}$, and $\mathrm{NO}_{\mathrm{x}}$ of $\sim 25$ pptv (Table 3a). Background $\mathrm{CO}$ decreases with altitude (Fig. 3a, Table 3a), suggesting that pollution is mainly mixed into the background and trapped at low altitudes. Background $\mathrm{O}_{3}$ and $\mathrm{NO}_{\mathrm{x}}$ remain relatively the same from spring to summer, but $\mathrm{CO}$ levels decrease to $\sim 100 \mathrm{ppbv}$ due to increased destruction by $\mathrm{OH}$ (Table $3 b$ ). Unlike in spring, CO in summer shows little dependence on altitude (Fig. 3b), indicating efficient vertical mixing.

Extensive aircraft measurements of the Arctic troposphere were available from the earlier Tropospheric $\mathrm{O}_{3}$ Production about the Spring Equinox (TOPSE) campaign in spring 2002 (Atlas et al., 2003) and the Arctic Boundary Layer Expedition (ABLE 3A) during summer 1988 (Harriss et al., 1992). Measurements from these previous missions show springtime mean $\mathrm{CO} \sim 154 \mathrm{ppbv}, \mathrm{O}_{3} \sim 67 \mathrm{ppbv}$, and $\mathrm{NO}_{\mathrm{x}} \sim$ 17 pptv (TOPSE) (Stroud et al., 2003) and summertime mean $\mathrm{CO} \sim 100 \mathrm{ppbv}, \mathrm{O}_{3} \sim 70 \mathrm{ppbv}$, and $\mathrm{NO}_{\mathrm{x}} \sim 10-50 \mathrm{pptv}$ (ABLE 3A) (Jacob et al., 1992) at 3-6 km in the Arctic mid-troposphere. Considering the likely variations associated with differences in air mass sampling and interannual variability, the ARCTAS measurements indicate that these important tropospheric trace gases, $\mathrm{CO}, \mathrm{NO}_{\mathrm{x}}$ and $\mathrm{O}_{3}$, have remained relatively unchanged in the Arctic mid-troposphere in the past two decades, despite the significant changes in processes that could have had a notable impact on the Arctic atmospheric composition, e.g., emissions regulation in $\mathrm{Eu}-$ rope and N. America, rapid industrialization in East Asia, and destruction of the stratospheric $\mathrm{O}_{3}$ layer.

The lowermost stratosphere, with low $\mathrm{CO}$, can reach as low as $6 \mathrm{~km}$ during spring, likely during low tropopause events (Fig. 3a). Significantly fewer samples of the lowermost stratospheric air (1\%) were sampled during summer at $>10 \mathrm{~km}$ (Fig. 3b). This is consistent with the seasonal growth of tropopause height from spring to summer. Frequent STE events have been observed throughout spring and summer. Air masses associated with fresh STE events are present at altitudes $>5 \mathrm{~km}$ (Fig. 3). Stratosphere-troposphere mixed air masses have higher $\mathrm{CO}$, compared to air in the lowermost 
(a) ARCTAS-A

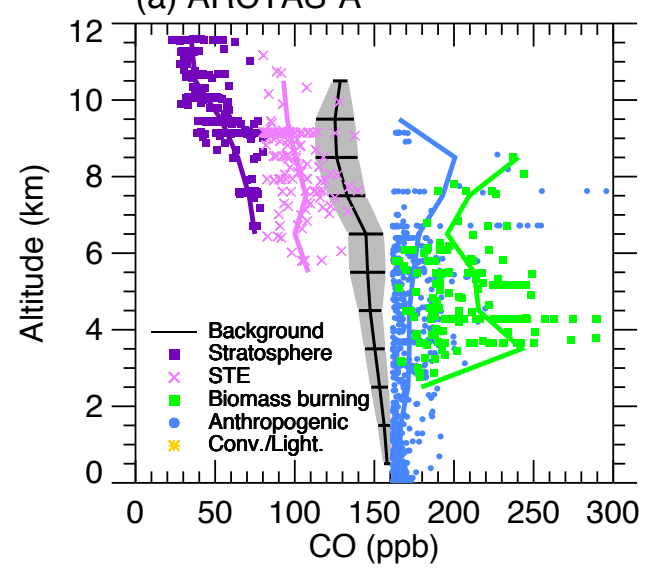

(b) ARCTAS-B

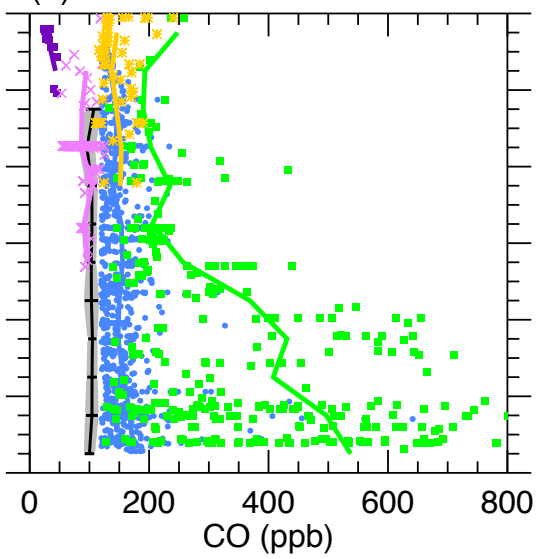

Fig. 3. Vertical profiles of CO during ARCTAS-A and ARCTAS-B. Black lines show the mean background CO at 1-km altitude bins, with gray shading indicating one standard deviation. We use colored symbols to show the individual air masses: stratosphere (purple), stratosphere-troposphere mixed (lilac), anthropogenic pollution (blue), biomass burning (green), and convection/lightning (yellow). The solid color lines indicate the vertical mean profiles of individual air masses.

stratosphere, reflecting mixing with tropospheric background air during stratosphere-to-troposphere transport.

The convective air masses observed during summer contain elevated CO (50\% enhancement as compared to background) (Table 3b), indicating freshly ventilated surface pollution. Anthropogenic pollution plumes are present from the surface to the upper troposphere throughout spring and summer and contain elevated $\mathrm{CO}(\sim 170 \mathrm{ppbv}$ in spring and $\sim 150$ ppbv in summer) (Fig. 3). Biomass burning plumes are confined in the mid troposphere during spring with a moderate increase in $\mathrm{CO}(\sim 220 \mathrm{ppbv})$ (Fig. 3a, Table 3a). The majority of the biomass burning air masses sampled during summer are fresh fire plumes in the lower troposphere with marked high CO ( 415 ppbv) (Fig. 3a, Table 3b). More detailed analysis on how anthropogenic pollution and Siberian (spring phase) and Canadian (summer phase) fire emissions impact atmospheric gas and aerosol composition and $\mathrm{O}_{3}$ production can be found in Singh et al. (2010) and Alvarado et al. (2010).

\section{Reactive nitrogen in the Arctic troposphere}

The abundance of $\mathrm{NO}_{\mathrm{x}}$ plays a determinative role in $\mathrm{O}_{3}$ production in the background troposphere (Lin et al., 1988; Sillman et al., 1990; Jaeglé et al., 1998; Wennberg et al., 1998). While $\mathrm{NO}_{\mathrm{x}}$ is present in the background atmosphere at low levels, it can be recycled between the radical forms and its long-lived reservoir species, which adds complexity to an accurate understanding of the $\mathrm{NO}_{\mathrm{x}}$ budget in the atmosphere. We analyze $\mathrm{NO}_{\mathrm{y}}\left(\mathrm{NO}_{\mathrm{x}}+\mathrm{PAN}+\mathrm{HNO}_{3}+\right.$ nitrates $)$ and its partitioning during ARCTAS to investigate the budget and source attribution of $\mathrm{NO}_{\mathrm{x}}$ in the Arctic and sub-Arctic troposphere. It is difficult to quantify the actual contribution of a certain source to reactive nitrogen species (same for $\mathrm{O}_{3}$ in Sect. 5) just based on observations. Therefore we examine the concentration of nitrogen species in individual air masses with respect to the background since the level of elevated concentration (shown in below as $\Delta$ values relative to the background concentrations) in an individual air mass reflects its potential as a source of nitrogen species.

\subsection{Reactive nitrogen in various air masses}

Reactive nitrogen in the background troposphere remains relatively constant from spring to summer ( $\sim 300-400 \mathrm{pptv})$ (Table 3 and Figs. 4 and 5). Nitrogen oxides ( 25 pptv) on average account for $5-10 \%$ of $\mathrm{NO}_{\mathrm{y}}$. PAN is the largest reservoir species $(\sim 200 \mathrm{pptv})$, accounting for $50 \%$ of $\mathrm{NO}_{\mathrm{y}}$ in spring and $\sim 70 \%$ in summer. The level of $\mathrm{HNO}_{3}$ is significantly lower than that of PAN, $\sim 30$ pptv in spring and $\sim 70$ pptv in summer. A small fraction of $\mathrm{NO}_{\mathrm{y}}(\sim 6 \%)$ is present as alkyl nitrates during summer.

The main sources of $\mathrm{NO}_{\mathrm{y}}$ in the troposphere at high latitudes are STE, and anthropogenic and biomass burning emissions (Fig. 4 and Table 3a). Combustion plumes are the major contributors of $\mathrm{NO}_{\mathrm{y}}$ in the middle troposphere mainly in the form of PAN and $\mathrm{NO}_{\mathrm{x}}$, but little $\mathrm{HNO}_{3}$. Air influenced by the stratosphere on average contains the highest level of $\mathrm{NO}_{\mathrm{y}}$ above $6 \mathrm{~km}$. Air masses associated with STE contain elevated levels of $\mathrm{NO}_{\mathrm{x}}$ and $\mathrm{HNO}_{3}$. Compared to air in the lowermost stratosphere, they contain much less $\mathrm{NO}_{\mathrm{y}}(40 \%$ of that in the lowermost stratosphere) and different $\mathrm{NO}_{\mathrm{y}}$ partitioning (less $\mathrm{HNO}_{3}$ and more PAN).

All sources, including anthropogenic and biomass burning emissions, convection, and STE contribute to $\mathrm{NO}_{\mathrm{y}}$ in the Arctic/sub-Arctic troposphere during summer (Fig. 5 and Table $3 b$ ). The $\mathrm{NO}_{\mathrm{y}}$ vs. $\mathrm{CO}$ relationship is more dispersed 

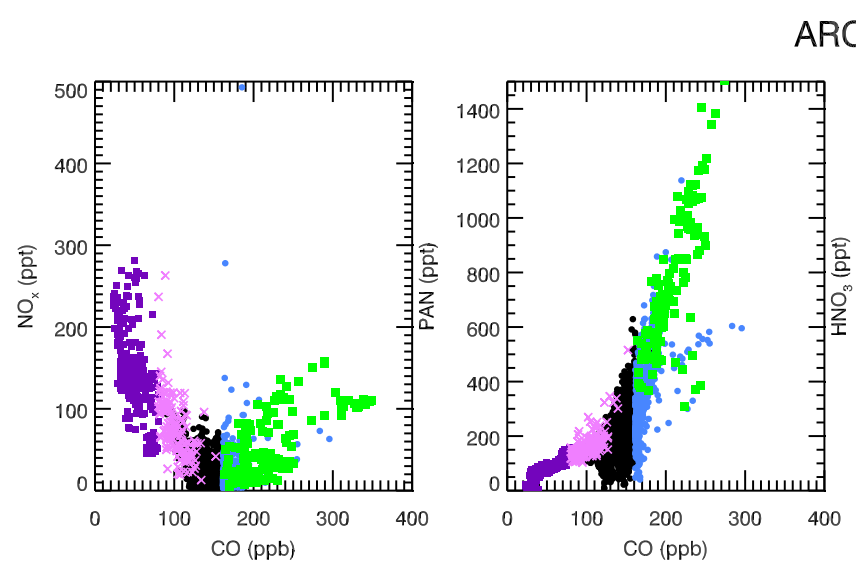

ARCTAS-A
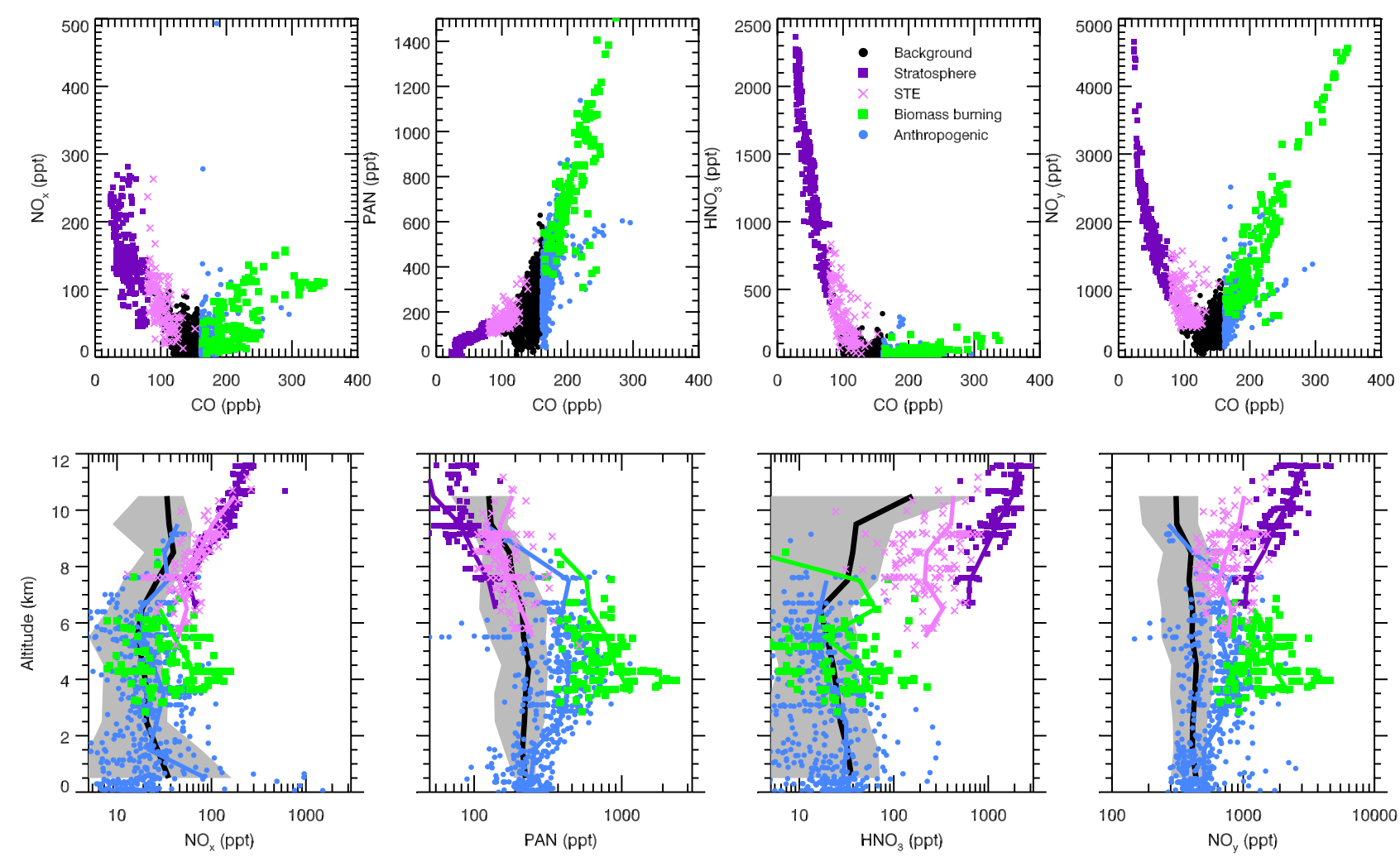

Fig. 4. Top panels: Scatter plots of $\mathrm{NO}_{\mathrm{x}}, \mathrm{PAN}, \mathrm{HNO}_{3}$, and $\mathrm{NO}_{\mathrm{y}}$ vs. $\mathrm{CO}$ during ARCTAS-A. Bottom panels: Similar to Fig. 3, but for 1-km binned verticle profiles of $\mathrm{NO}_{\mathrm{x}}, \mathrm{PAN}, \mathrm{HNO}_{3}$, and $\mathrm{NO}_{\mathrm{y}}$ during ARCTAS-A. Background air is shown in black with the other air masses highlighted in color: stratosphere (purple), stratosphere-troposphere mixed (lilac), anthropogenic pollution (blue) and biomass burning (green).

during summer, compared to a clear and compact correlation in individual air masses in spring, implying more mixing among air masses of different origin. Biomass burning air masses contain high concentrations of $\mathrm{NO}_{\mathrm{x}}, \mathrm{PAN}$, and alkyl nitrates $(\mathrm{AN})\left(\Delta \mathrm{NO}_{\mathrm{x}} \sim 600 \mathrm{pptv}, \Delta \mathrm{PAN} \sim 750 \mathrm{pptv}\right.$, $\Delta \mathrm{ANs} \sim 200 \mathrm{pptv}$ ) and is the dominant contributor to $\mathrm{NO}_{\mathrm{y}}$ $\left(\Delta \mathrm{NO}_{\mathrm{y}} \sim 1700 \mathrm{pptv}\right)$ in the mid and lower troposphere. Anthropogenic emissions also contribute, but their impacts are much less pronounced $\left(\Delta \mathrm{NO}_{\mathrm{y}} \sim 250 \mathrm{pptv}, \Delta \mathrm{NO}_{\mathrm{x}} \sim 70 \mathrm{pptv}\right.$, $\triangle \mathrm{PAN} \sim 150 \mathrm{pptv}$, and no elevated $\mathrm{ANs}$ and $\mathrm{HNO}_{3}$ ). In the upper troposphere $(>6 \mathrm{~km})$, convection, STE, and biomass burning all contribute significantly to $\mathrm{NO}_{\mathrm{y}}$. Convection is the dominant source of $\mathrm{NO}_{\mathrm{x}}\left(\Delta \mathrm{NO}_{\mathrm{x}}=600 \mathrm{pptv}\right)$ while biomass burning pollution is the dominant contributor to PAN. Air masses influenced by STE contain high $\mathrm{NO}_{\mathrm{y}}$, comparable to that in convective air masses. They display high $\mathrm{NO}_{\mathrm{x}}\left(\Delta \mathrm{NO}_{\mathrm{x}} \sim 100\right.$ pptv $)$ and $\mathrm{HNO}_{3}\left(\Delta \mathrm{HNO}_{3} \sim 400 \mathrm{pptv}\right)$ as stratospheric air is commonly enriched with $\mathrm{NO}_{\mathrm{x}}$ and $\mathrm{HNO}_{3}$. They also have significantly elevated in PAN ( $50 \%$ more than the background), with a mean concentration (320 pptv) almost comparable to that in anthropogenic plumes (350 pptv).

\subsection{PAN in air masses influenced by STE}

Using $\mathrm{CO}$ as a proxy for transport and air mass inter-mixing, we examine how mixing ratios of reactive nitrogen species change as air of stratospheric origin mixes with tropospheric background air during STE events (Parrish et al., 1998). As it mixes with tropospheric air, an air parcel of stratospheric origin moves along the mixing line (thick green dashed lines) in a scatter plot (Fig. 6). (We refer to tropospheric air masses influenced by stratospheric air as "stratosphere-troposphere mixed air masses" hereafter.) When active chemical production and/loss of $\mathrm{NO}_{\mathrm{y}}$ species occurs, the air parcel deviates from the mixing line. Wet scavenging adds some complexity as it is a significant loss of $\mathrm{HNO}_{3}$ (therefore $\mathrm{NO}_{\mathrm{y}}$ ) in the troposphere in summer and thus lowering the mean concentrations of $\mathrm{HNO}_{3}$ and $\mathrm{NO}_{\mathrm{y}}$ in the tropospheric background air. The majority of the observed mixing ratios of $\mathrm{NO}_{\mathrm{x}}, \mathrm{HNO}_{3}, \mathrm{NO}_{\mathrm{y}}$, and the springtime PAN in the stratosphere-troposphere mixed air masses is within the envelope of variations that can be explained by mixing alone (thin gray dashed lines). The observed mean PAN in the summertime stratosphere-troposphere mixed air is $320 \mathrm{pptv}$. 


\section{ARCTAS-B}
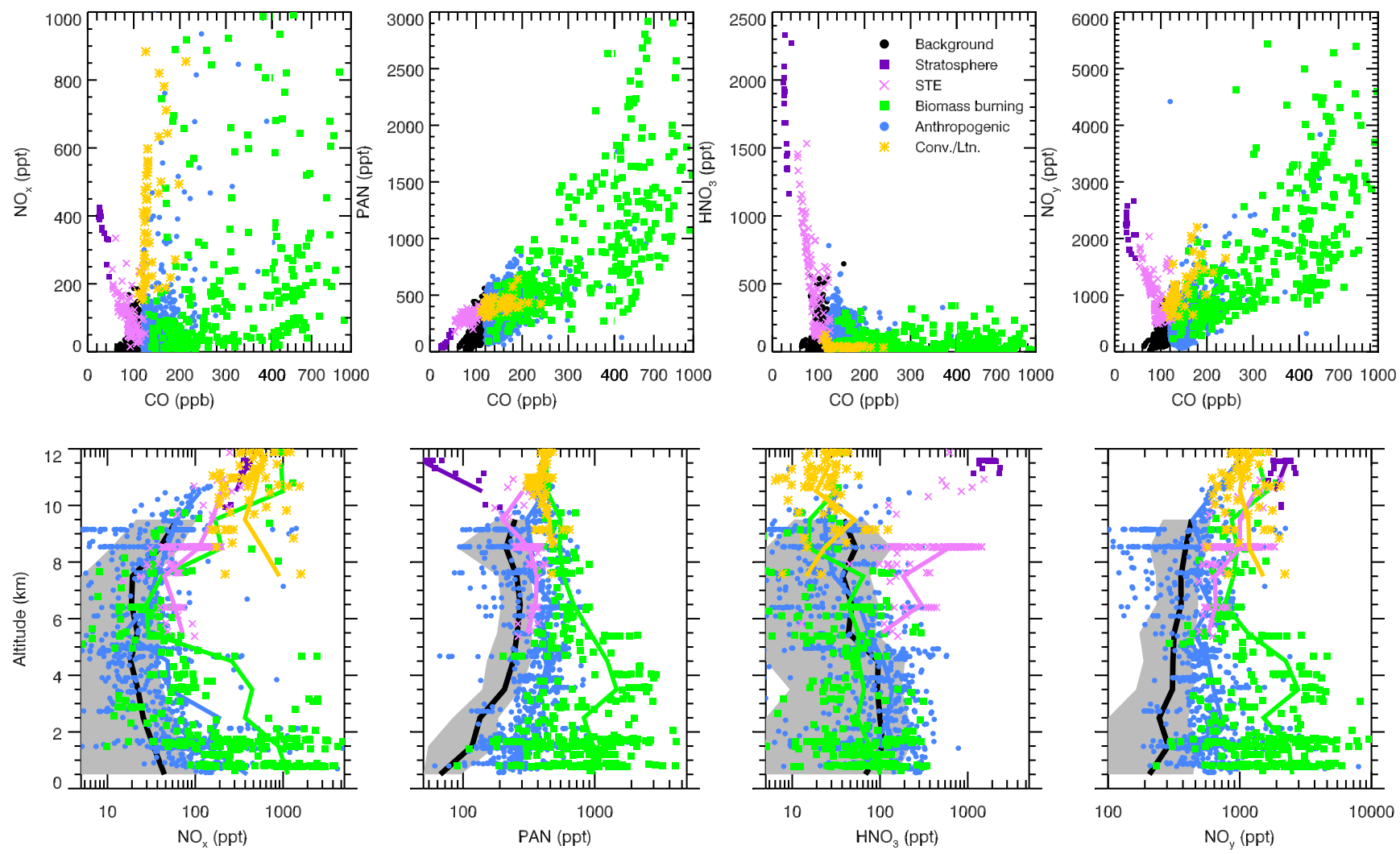

Fig. 5. Same as Fig. 4 but for ARCTAS-B. Note part of the x-axis in the top panels for CO between 400-1000 ppbv is condensed in length for better visualization of the air mass characteristics.

Assuming that the mean $\mathrm{CO}$ of $\sim 90 \mathrm{ppbv}$ in the stratospheretroposphere mixed air masses results from mixing stratospheric air with tropospheric background, PAN can increase to $\sim 220$ pptv assuming PAN and CO increase proportionally. Although the air masses that we identified as being influenced by STE display low levels of CO $(<160 \mathrm{ppbv}$ for spring and $<120 \mathrm{ppbv}$ for summer), it is possible that these air masses might experience some mixing with combustion plumes, which are considered the main sources of PAN in the atmosphere (e.g., Singh et al., 1992; Alvarado et al., 2010). Air masses influenced by convection sampled during ARCTAS-B also display elevated levels of PAN (Table $3 b)$. Mixing with these tropospheric plumes can potentially increase the level of PAN. However, the mixing lines between stratospheric air and anthropogenic, biomass burning, and convective air masses between 6-12 km fall closely to that of the background air and do not help much in explaning the observed high level of PAN in at least half of the stratosphere-troposphere mixed air masses.

What could have contributed to the high PAN observed in air influenced by STE during ARCTAS in summer? One possible explanation is active photochemical production and conversion of nitrogen from $\mathrm{HNO}_{3}$ to PAN. In our earlier modeling study, Liang et al. (2009), we conducted a detailed budget analysis of $\mathrm{NO}_{\mathrm{y}}$ in the Arctic using the GMI CTM which contains a fully-coupled tropospheric and stratospheric chemistry scheme. The model results suggest that significant conversion occurs of nitrogen from $\mathrm{HNO}_{3}$ to $\mathrm{NO}_{\mathrm{x}}$ and then to PAN as air of stratospheric origin mixes into air in the upper troposphere in the Arctic during summer.

We now analyze the ARCTAS-B measurements together with box model results to examine if indeed there exists active conversion of nitrogen from $\mathrm{HNO}_{3}$ to PAN in the stratosphere-troposphere mixed air masses. Fig. 7 shows the concentrations of several trace gases in a stratospheretroposphere mixed plume (low $\mathrm{CO}$ and high $\mathrm{O}_{3}$ ) sampled by the DC- 8 aircraft on 9 July 2008. This is a relatively fresh stratosphere-troposphere mixed plume with high $\mathrm{NO}_{\mathrm{x}}$, $\mathrm{HNO}_{3}$, and medium PAN ( $\left.\sim 300 \mathrm{pptv}\right)$. The DC-8 aircraft sampled another stratosphere-troposphere mixed plume on 8 July 2008 (Fig. 8). This plume contains two subplumes: A and B. Subplume A is a fresh stratosphere-troposphere mixed plume with chemical composition similar to that of the 9 July plume (high $\mathrm{NO}_{\mathrm{x}}, \mathrm{HNO}_{3}$, and medium PAN). Subplume $\mathrm{B}$ is an aged stratosphere-troposphere mixed plume with relatively low $\mathrm{NO}_{\mathrm{x}}, \mathrm{HNO}_{3}$, and high PAN (maximum 
(a) ARCTAS-A

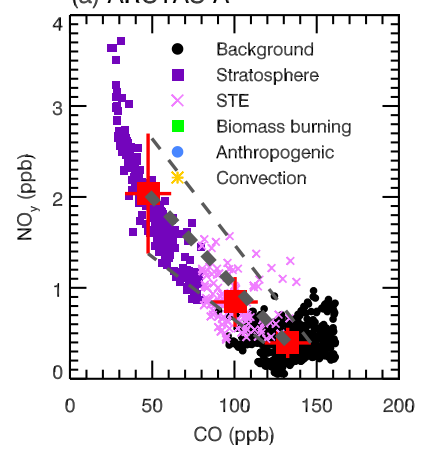

(e) ARCTAS-B

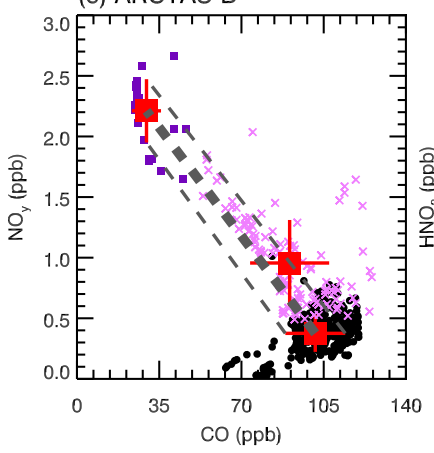

(b) ARCTAS-A

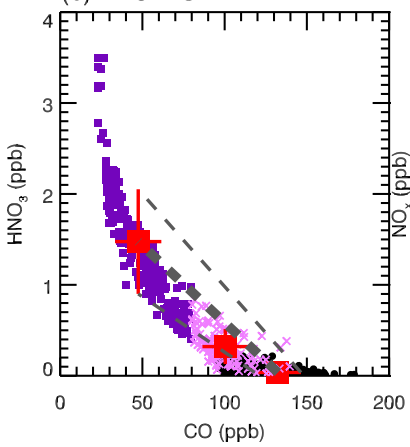

(f) ARCTAS-B

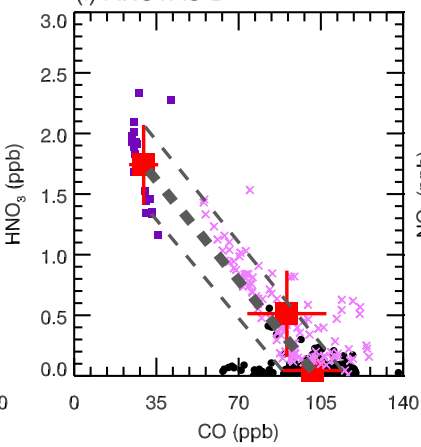

(c) ARCTAS-A

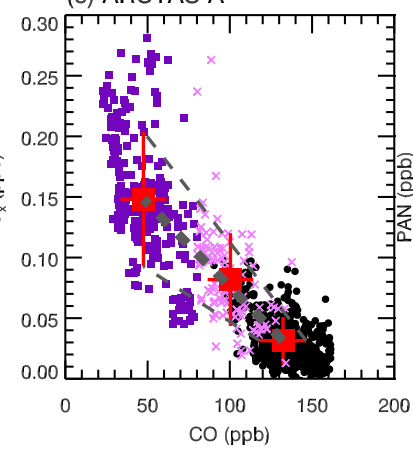

(g) ARCTAS-B

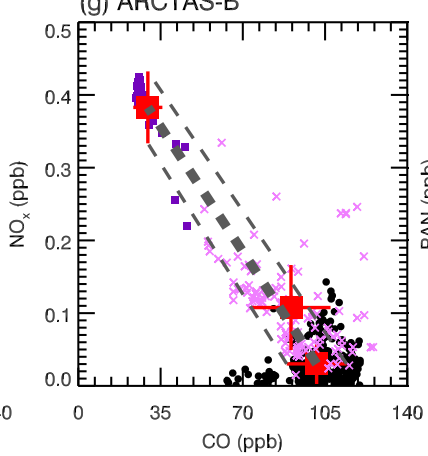

(d) ARCTAS-A

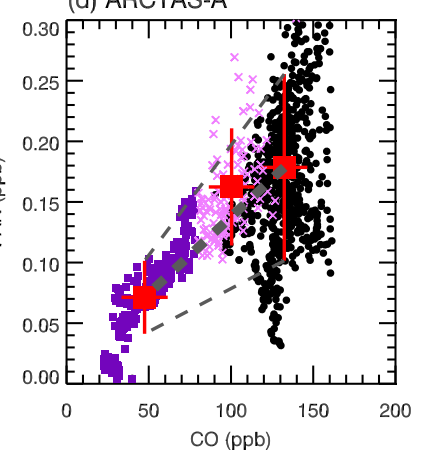

(h) ARCTAS-B

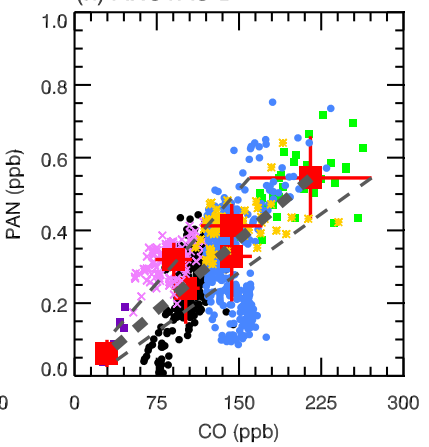

Fig. 6. Scatter plots of $\mathrm{NO}_{\mathrm{x}}, \mathrm{PAN}, \mathrm{HNO}_{3}$, and $\mathrm{NO}_{\mathrm{y}}$ vs. $\mathrm{CO}$ in the background air between 6-12 km (black dots), stratospheric air (purple squares), and stratosphere-troposphere mixed air (lilac crosses) for ARCTAS-A (top panels) and ARCTAS-B (bottom row). The mean mixing ratios within each air mass is plotted (red squares) with horizontal bars indicating one standard deviation of CO and vertical bars for one standard deviation of the corresponding reactive nitrogen species. This figure demonstrates how trace gas mixing ratios change as air of stratospheric-origin mixes with background air during STE. Note in panel (h) we have added the biomass burning, anthropogenic and convective air masses between 6-12 km as well to demonstrate the impact on PAN in the stratosphere-troposphere mixed air if mixing with these tropospheric air masses occurs. For air that do not experience active chemical production and loss of reactive nitrogen species, as well as wet scavenging (important for $\mathrm{HNO}_{3}$, and therefore $\mathrm{NO}_{y}$ ), an air parcel should in general follow the mixing line (thick gray dashed lines) as it descends into the troposphere. The thin gray dashed lines outline the envelope of mixing lines when allowing one sigma deviation from the mean concentration in both the stratospheric air and tropospheric backgroud.

$\sim 400$ pptv). The differences in $\mathrm{NO}_{\mathrm{y}}$ partitioning between the fresh and aged stratosphere-troposphere mixed plumes are likely linked to photochemical process which occur when air of stratospheric origin is mixed with tropospheric background: stratospheric $\mathrm{NO}_{\mathrm{x}}$ and $\mathrm{HNO}_{3}$ are converted to PAN in the presence of tropospheric VOCs.

We examine the photochemical equilibium state within three types of air masses using the NASA Langley box model (Olson et al., 2004): the mean tropospheric background between $6-12 \mathrm{~km}$, the lowermost stratosphere, and the stratosphere-troposphere mixed air (Fig. 9). We conduct two base simulations initiated with mean observed chemical composition (Table 3b) in the upper tropospheric background (BCG) (Fig. 9a) and the lower stratosphere (STR) (Fig. 9b), respectively, and ran the box model for 20 days. The BCG case shows that in general the $\mathrm{NO}_{\mathrm{y}}$ partitioning in the background air masses sampled during ARCTAS-B is not at equilibium and PAN is steadily converted to $\mathrm{HNO}_{3}$ at a rate of $\sim 2$ pptv day ${ }^{-1}$. The $\mathrm{NO}_{\mathrm{y}}$ paritioning in the sampled lower stratospheric air is approximately at equilibrium (Fig. 9b).

We now illustrate what happens when lower stratospheric air mixes with tropospheric background air. We initialize the box model with trace gas concentrations assuming a typical BCG point sampled by the 8 July flight mixes with a typical STR point sampled by the same flight (Fig. 9c). A mixing ratio of $70 \%$ BCG and $30 \%$ STR air sampled near the STR point by the 8 July flight is used which yields $\mathrm{CO}$ and $\mathrm{CH}_{4}$ levels approximately close to those sampled in the stratosphere-troposphere mixed subplume A on 8 July (Fig. 8). Within the simulated stratospheretroposphere mixture, there is active conversion from $\mathrm{HNO}_{3}$ to $\mathrm{PAN}$ at $\sim 3.7 \mathrm{pptv}^{-1} \mathrm{day}^{-1}$ (net $\sim 75 \mathrm{pptv}$ production of PAN in 20 days) and the mixture is not yet reaching equilibium after the 20 days' simulation period. A more generalized case initialized with a mixture of mean BCG concentration (70\%) and mean STR air (30\%) shows similar net conversion 


\section{ARCTAS DC8 FLT 20080709}
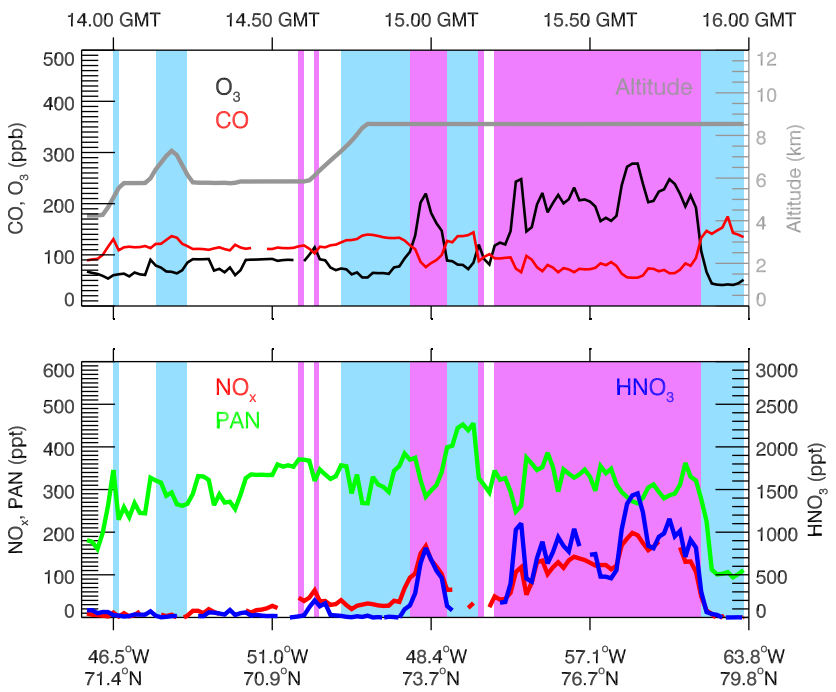

Fig. 7. Time series of aircraft altitude (top panel, gray line), observed $\mathrm{CO}, \mathrm{O}_{3}$ (top panel, red and black lines), $\mathrm{NO}_{\mathrm{x}}, \mathrm{PAN}$, $\mathrm{HNO}_{3}$ (red, green and blue lines in middle panel) between 14:0016:00 GMT for DC-8 flight on 9 July 2008. We highlight the identified air masses in color shading: anthropogenic plumes (light blue) and stratosphere-troposphere mixed air (lilac).

\section{ARCTAS DC8 FLT 20080708}
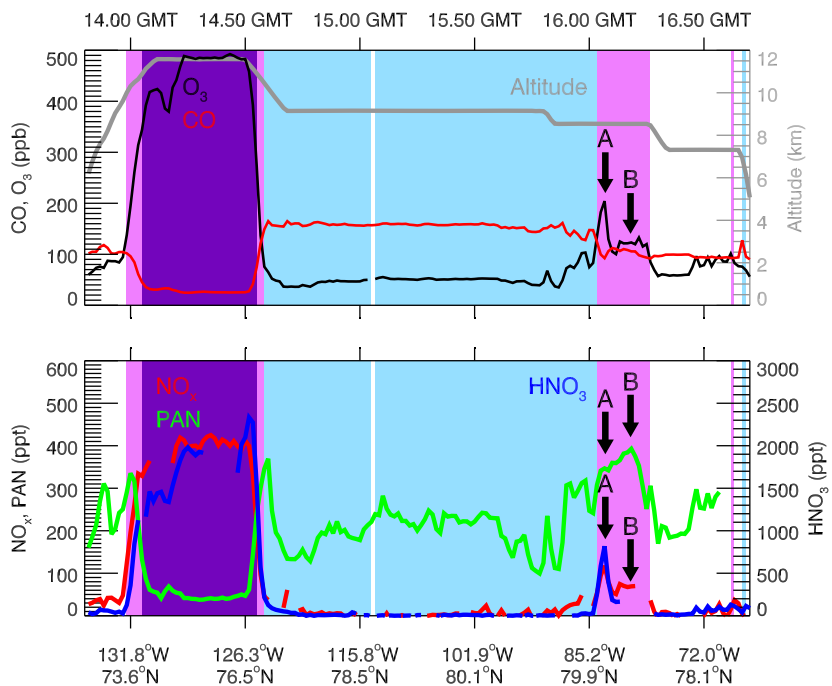

Fig. 8. Same as Fig. 7 but for DC-8 flight on 8 July 2008. Similarly, we highlight the identified air masses in color shading: anthropogenic plumes (light blue), stratospheric air (purple), stratosphere-troposphere mixed air (lilac). The thick black arrows near 16:00 GMT indicate the two sub-plumes (A and B) within the same stratosphere-troposphere mixed air mass (Sect. 4.2). from $\mathrm{HNO}_{3}$ to PAN but at a slower rate, $\sim 2 \mathrm{pptv}_{\text {day }}{ }^{-1}$ (net $\sim 40$ pptv formation of PAN in 20 days) (Fig. 9d).

While the lower stratospheric or upper tropospheric background alone displays zero production or net destruction of PAN, the mixture of the two during STE events provides a unique environment, where tropospheric air which has high VOC and $\mathrm{H}_{2} \mathrm{O}$ meets stratospheric air which contains high $\mathrm{NO}_{\mathrm{y}}$ and $\mathrm{O}_{3}$, resulting in the active photochemical production of PAN. This occurs for two reasons: (i) increased degradation of ethane due to increases in $\mathrm{OH}$ (Table 3b) (the increase in $\mathrm{OH}$ in stratosphere-troposphere mixed air is due to the mix of $\mathrm{O}_{3}$-rich stratospheric air with moist tropospheric air), (ii) increased PAN formation mainly through the following reactions:

$\mathrm{C}_{2} \mathrm{H}_{6}+\mathrm{OH} \rightarrow \mathrm{C}_{2} \mathrm{H}_{5} \mathrm{O}_{2}+\mathrm{H}_{2} \mathrm{O}$

$\mathrm{C}_{2} \mathrm{H}_{5} \mathrm{O}_{2}+\mathrm{NO} \rightarrow \mathrm{CH}_{3} \mathrm{CHO}+\mathrm{NO}_{2}+\mathrm{HO}_{2}$

$\mathrm{CH}_{3} \mathrm{CHO}+\mathrm{OH} \rightarrow \mathrm{CH}_{3} \mathrm{C}(\mathrm{O}) \mathrm{O}_{2}$

\section{$\mathrm{CH}_{3} \mathrm{C}(\mathrm{O}) \mathrm{O}_{2}+\mathrm{NO}_{2} \leftrightarrow \mathrm{PAN}$}

A simplified version of the box model, which only includes $\mathrm{C}_{2} \mathrm{H}_{6}, \mathrm{CH}_{3} \mathrm{CHO}$ and their intermediate products, $\mathrm{CH}_{3} \mathrm{C}(\mathrm{O}) \mathrm{O}_{2}, \mathrm{NO}_{\mathrm{x}}, \mathrm{PAN}, \mathrm{HNO}_{3}$, and constrained with the observed $\mathrm{OH}, \mathrm{HO}_{2}$, and photolysis rates, indicates the above chemistry alone is able to explain the $\sim 2$ pptv day $^{-1}$ PAN production calculated by the Langley box model (see Supplement, Fig. S3). Additional sensitivity runs suggest that the PAN production rate is most sensitive to the $\mathrm{OH}$ as well as $\mathrm{NO}_{\mathrm{x}}$ concentrations. Although we successfully demonstrated that the mixing during STE events leads to the photochemical production of PAN, the calculated box model results were only able to explain approximately $40 \%$ of the observed 100 pptv increase in PAN that could not be explained by mixing. It is important to note that our box model calculation is an idealized simplification of the real atmospheric chemical processes. The calculated $\mathrm{OH}$ and $\mathrm{NO}, \mathrm{NO}_{2}$ levels also differ slightly from the observed values, which can impact the calculated PAN production rate. It is desirable to conduct a comprehensive analysis using 3-dimensional chemical transport model for a better quantification of the impact of STE on tropospheric PAN production.

\section{Ozone and ozone production in the Arctic troposphere}

The photochemical balance between $\mathrm{O}_{3}$ production and loss is an intricate play between $\mathrm{NO}_{\mathrm{x}}, \mathrm{HO}_{\mathrm{x}}$, and $\mathrm{O}_{3}$ (Jaeglé et al., 1998; Wennberg et al., 1998). In this section, we examine $\mathrm{O}_{3}$, the $\mathrm{O}_{3}$ production rate, and ozone's dependence on $\mathrm{NO}_{\mathrm{x}}$ and $\mathrm{HO}_{\mathrm{x}}$ to understand the sources of $\mathrm{O}_{3}$ in the Arctic and sub-Arctic troposphere. 
(a) Mean Background

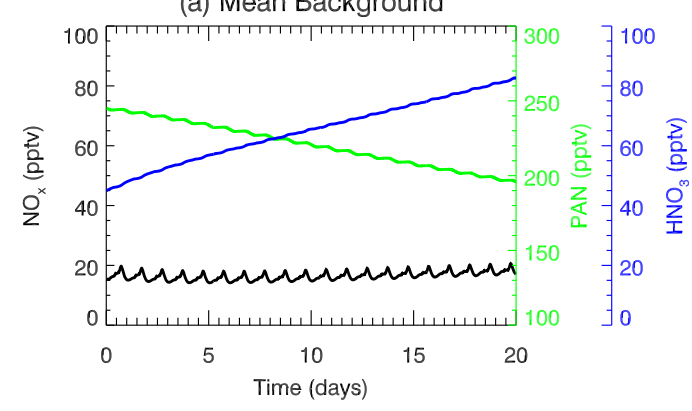

(c) STE Point

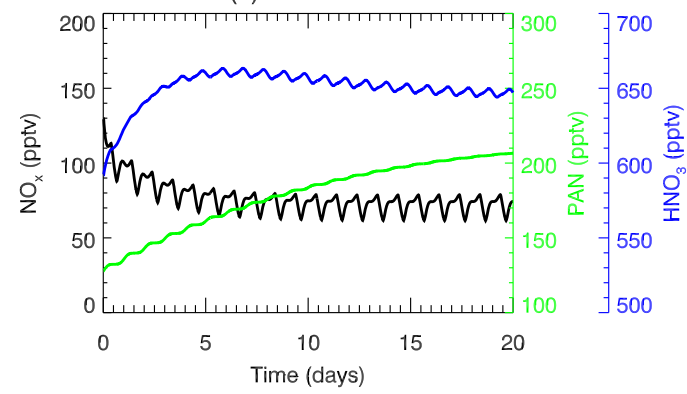

(b) Mean Stratosphere

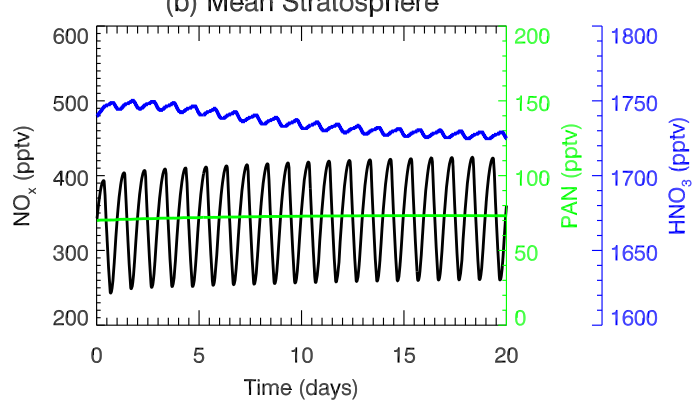

(d) Mean STE

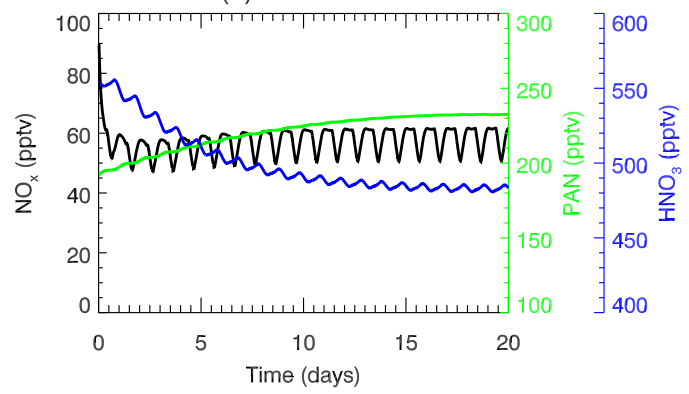

Fig. 9. Time-dependent box-model calculation of $\mathrm{NO}_{\mathrm{x}}, \mathrm{PAN}$, and $\mathrm{HNO}_{3}$ partitioning in (a) mean upper tropospheric background and (b) mean lower stratospheric air. We also show results from a third box-model calculation aiming to simulate the stratosphere-troposphere mixed subplume A sampled by the July 8 flight (c). We assume injection of the lower stratospheric air into the background air mass with a mixture ratio of $30 \%$ stratospheric air vs. $70 \%$ background air which yields approximately the measured $\mathrm{CO}$ and $\mathrm{CH}_{4}$ in the stratosphere-troposphere mixed plume. (d) shows what happens in a more generalized stratosphere-troposphere mixed case assuming $30 \%$ stratospheric air mixes with $70 \%$ tropospheric air using the measured mean concentrations in the two air masses during ARCTAS-B.

\subsection{Dependence of ozone production on $\mathrm{NO}_{\mathrm{x}}$ and $\mathrm{HO}_{\mathrm{x}}$}

Ozone is produced in the troposphere mainly through the following chemical reactions,

$\mathrm{OH}+\mathrm{CO} \stackrel{\mathrm{O}_{2}}{\rightarrow} \mathrm{HO}_{2}+\mathrm{CO}_{2}$

$\mathrm{HO}_{2}+\mathrm{NO} \rightarrow \mathrm{OH}+\mathrm{NO}_{2}$

$\mathrm{NO}_{2}+h v \rightarrow \mathrm{NO}+\mathrm{O}$

$\mathrm{O}+\mathrm{O}_{2} \rightarrow \mathrm{O}_{3}$

Net: $\mathrm{CO}+2 \mathrm{O}_{2} \rightarrow \mathrm{CO}_{2}+\mathrm{O}_{3}$ with Reaction (2) being the rate-limiting step. Ozone can also be produced from reaction of peroxy radicals $\left(\mathrm{RO}_{2}\right)$ with NO:

$\mathrm{RO}_{2}+\mathrm{NO} \rightarrow \mathrm{CH}_{2} \mathrm{O}+\mathrm{HO}_{2}+\mathrm{NO}_{2}$

Ozone is destroyed in the troposphere through photolysis and reaction with $\mathrm{HO}_{\mathrm{x}}\left(\mathrm{OH}+\mathrm{HO}_{2}\right)$ :

$\mathrm{O}_{3}+h v \rightarrow \mathrm{O}\left({ }^{1} \mathrm{D}\right)+\mathrm{O}_{2}$

$\mathrm{O}\left({ }^{1} \mathrm{D}\right)+\mathrm{H}_{2} \mathrm{O} \rightarrow 2 \mathrm{OH}$

$\mathrm{HO}_{2}+\mathrm{O}_{3} \rightarrow \mathrm{OH}+2 \mathrm{O}_{2}$

$\mathrm{OH}+\mathrm{O}_{3} \rightarrow \mathrm{HO}_{2}+\mathrm{O}_{2}$
We use the $\mathrm{O}_{3}$ production and loss rates calculated by the NASA Langley box model (Olson et al., 2004) constrained by chemical and physical parameters measured by the DC- 8 aircraft. For this study, we use mostly the instantaneous production and loss rates from the box model calculation. Note that the catalytic destruction of $\mathrm{O}_{3}$ by bromine radicals is also included in the Langley box model to account for the $\mathrm{O}_{3}$ depletion events sampled during ARCTAS. For simplicity and clarity, we exclude data that contain elevated bromine (BrO $>1.5 \mathrm{pptv}$ ). The calculated net $\mathrm{O}_{3}$ production (formationdestruction) rates, $\mathrm{NP}\left(\mathrm{O}_{3}\right)$, can be approximated as:

$$
\begin{aligned}
& \mathrm{NP}\left(\mathrm{O}_{3}\right)=\mathrm{P}\left(\mathrm{O}_{3}\right)-\mathrm{L}\left(\mathrm{O}_{3}\right) \\
& =\mathrm{K}_{2}\left[\mathrm{HO}_{2}\right][\mathrm{NO}]+\mathrm{K}_{5}\left[\mathrm{RO}_{2}\right][\mathrm{NO}] \\
& -\mathrm{K}_{6}\left[\mathrm{H}_{2} \mathrm{O}\right]\left[\mathrm{O}\left({ }^{1} \mathrm{D}\right)\right]-\mathrm{K}_{7}\left[\mathrm{HO}_{2}\right]\left[\mathrm{O}_{3}\right]-\mathrm{K}_{8}[\mathrm{OH}]\left[\mathrm{O}_{3}\right]
\end{aligned}
$$

Figure 10 shows the dependence of the calculated instantaneous $\mathrm{NP}\left(\mathrm{O}_{3}\right)$ on levels of $\mathrm{NO}_{\mathrm{x}}$ during ARCTAS for high and low $\mathrm{HO}_{\mathrm{x}}$ conditions and vice versa. While $\mathrm{NO}_{\mathrm{x}}$ remains relatively unchanged from spring to summer, the $\mathrm{O}_{3}$ production rate during summer is $\sim 10$ times higher than that calculated for spring, due to active photochemistry with increasing insolation and humidity. The level of $\mathrm{NO}_{\mathrm{x}}$ plays a determinative role in the photochemical production of $\mathrm{O}_{3}$. The $\mathrm{NP}\left(\mathrm{O}_{3}\right)$ increases rapidly with increasing levels of $\mathrm{NO}_{\mathrm{x}}$, 

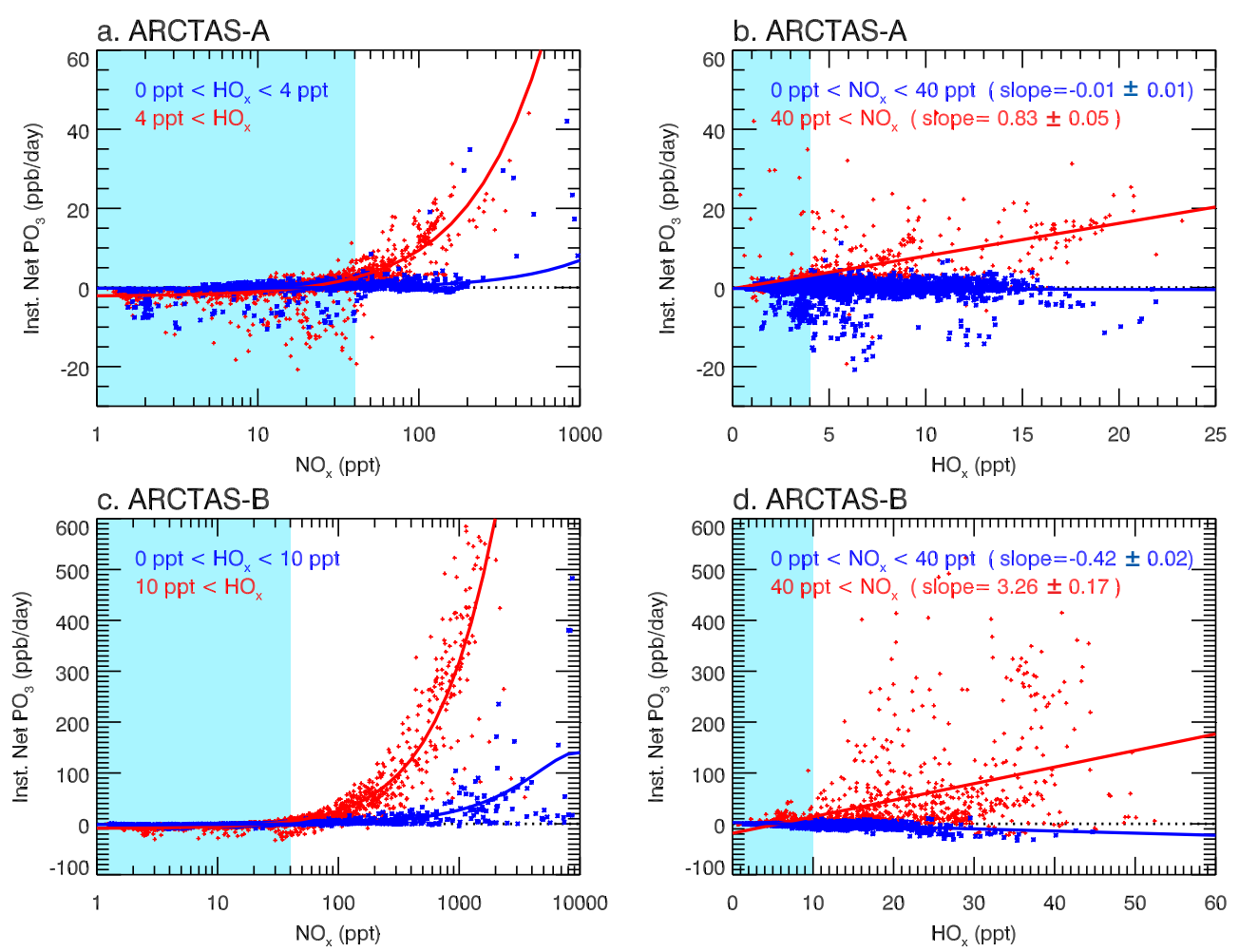

Fig. 10. (a, c): the dependence of the instantaneous $\mathrm{NP}\left(\mathrm{O}_{3}\right)$ on $\mathrm{NO}_{\mathrm{x}}$ for low (blue symbols) and high (red symbols) $\mathrm{HO}$ x levels during ARCTAS. (b, d): the dependence of the instantaneous $\mathrm{NP}\left(\mathrm{O}_{3}\right)$ on $\mathrm{HO}_{\mathrm{x}}$ for low (blue symbols) and high (red symbols) $\mathrm{NO}_{\mathrm{x}}$ levels. The instantaneous $\mathrm{NP}\left(\mathrm{O}_{3}\right)$ are calculated by the NASA Langley box model (Olson et al., 2004) constrained by chemical and physical parameters measured by the DC-8 aircraft. We separate data into low $\mathrm{NO}_{\mathrm{x}}\left(\mathrm{HO}_{\mathrm{x}}\right)$ and high $\mathrm{NO}_{\mathrm{x}}\left(\mathrm{HO}_{\mathrm{x}}\right)$ population using the mean conditions of the corresponding season, $\mathrm{NO}_{\mathrm{x}} \sim 40$ pptv and $\mathrm{HO}_{\mathrm{X}} \sim 4$ pptv in spring and $\mathrm{NO}_{\mathrm{X}} \sim 40$ pptv and $\mathrm{HO}_{\mathrm{x}} \sim 10$ pptv in summer. The low $\mathrm{NO}_{\mathrm{X}}\left(\mathrm{HO}_{\mathrm{x}}\right)$ regime is highlighted in aqua shading on each panel.

suggesting that the Arctic troposphere is in the $\mathrm{NO}_{\mathrm{x}}$-limited regime. The rate $\mathrm{NP}\left(\mathrm{O}_{3}\right)$ increases with increasing $\mathrm{NO}_{\mathrm{x}}$ is dependent on the abundance of $\mathrm{HO}_{\mathrm{x}}$ radicals. When $\mathrm{HO}_{\mathrm{x}}$ is high ( $>4$ pptv in spring and $>10$ pptv in summer which occur mostly in combustion plumes), the $\mathrm{NP}\left(\mathrm{O}_{3}\right)$ increases drastically as $\mathrm{NO}_{\mathrm{x}}$ increases. At low $\mathrm{HO}_{\mathrm{x}}$ concentrations (background and air of stratospheric origin), the $\mathrm{NP}\left(\mathrm{O}_{3}\right)$ displays a weak increase with increasing $\mathrm{NO}_{\mathrm{x}}$ as both production (Reaction 2) and loss (Reactions 7 and 8 ) are slow. The dependence of $\mathrm{NP}\left(\mathrm{O}_{3}\right)$ on $\mathrm{HO}_{\mathrm{x}}$ is rather complex, impacted by levels of $\mathrm{NO}_{\mathrm{x}}$. On the one hand, $\mathrm{HO}_{\mathrm{x}}$ can enhance $\mathrm{O}_{3}$ production through Reaction (2). On the other hand, it provides a reaction partner for $\mathrm{O}_{3}$ destruction in Reactions (7) and (8). At high $\mathrm{NO}_{\mathrm{x}}$ levels (e.g., fresh combustion plumes, STE events, and convection), the $\operatorname{NP}\left(\mathrm{O}_{3}\right)$ shows a positive dependence on $\mathrm{HO}_{\mathrm{x}}$. When $\mathrm{NO}_{\mathrm{x}}$ is low $(<40$ pptv, i.e., background and aged pollution plumes), the $\mathrm{NP}\left(\mathrm{O}_{3}\right)$ is either insensitive to $\mathrm{HO}_{\mathrm{x}}$ (spring) or decreases with increasing $\mathrm{HO}_{\mathrm{x}}$ and becomes negative when $\mathrm{HO}_{\mathrm{x}}$ exceeds 20 pptv (summer).

\section{$\begin{array}{ll}5.2 & \mathrm{O}_{3} \\ & \text { and } \mathrm{O}_{3} \text { production in various air masses }\end{array}$}

The mean background $\mathrm{O}_{3}$ in the Arctic and sub-Arctic troposphere remains relatively constant from spring to summer, increasing with altitude from $30-40 \mathrm{ppbv}$ at the surface to 60 $70 \mathrm{ppbv}$ in the middle and upper troposphere (Fig. $11 \mathrm{~b}$ and e and Table 3$)$. The middle troposphere $(3-8 \mathrm{~km})$ shows net $\mathrm{O}_{3}$ destruction while the lower $(<3 \mathrm{~km})$ and upper troposphere $(>8 \mathrm{~km})$ has $\mathrm{NP}\left(\mathrm{O}_{3}\right)$ greater than zero (net $\mathrm{O}_{3}$ formation), regulated by the mean $\mathrm{NO}_{\mathrm{x}}$ concentration. $\mathrm{NO}_{\mathrm{x}} \sim 20 \mathrm{pptv}$ is a critical level (Klonecki and Levy, 1997) in the Arctic troposphere that separates the middle troposphere $\left(\mathrm{NO}_{\mathrm{x}}<20 \mathrm{pptv}\right.$, net $\mathrm{O}_{3}$ destruction regime, Fig. $11 \mathrm{c}$ and f) from the lower and upper troposphere where $\mathrm{NO}_{\mathrm{x}}$ exceeds 20 pptv, hence, net $\mathrm{O}_{3}$ formation (Fig. 11c and f).

Air masses associated with recent STE intrusions have a mean $\mathrm{O}_{3}$ mixing ratio of $\sim 150 \mathrm{ppbv}$ (vs. $\sim 70 \mathrm{ppbv}$ in background air between 6-12 km), implying that the direct transport of high $\mathrm{O}_{3}$ from the stratosphere to the troposphere during STE events are a significant source of $\mathrm{O}_{3}$ in the Arctic during spring and summer, particularly in the upper troposphere (Fig. 11). In addition, air masses influenced 


\section{ARCTAS-A}
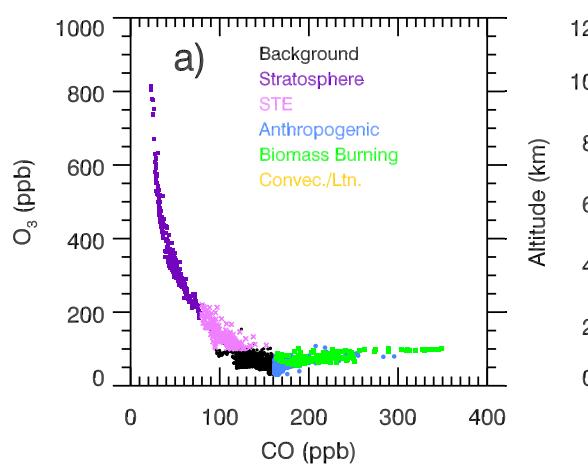

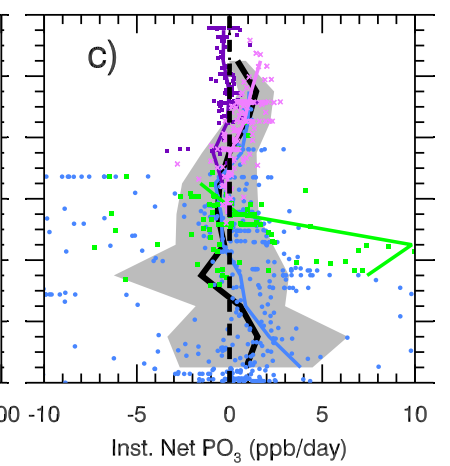

ARCTAS-B
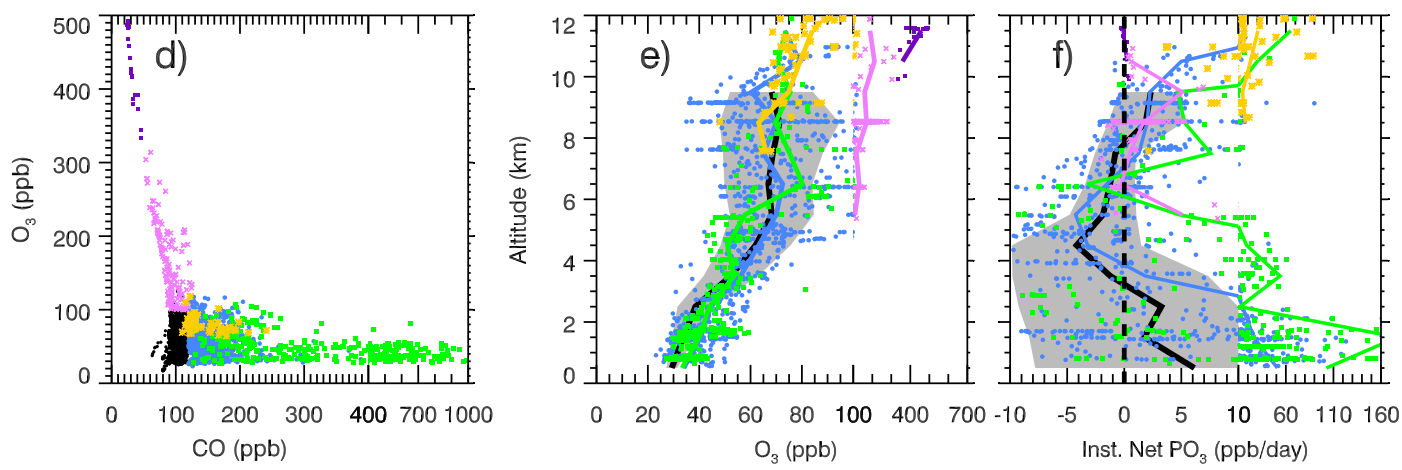

Fig. 11. (a): scatter plot of $\mathrm{O}_{3}$ vs. CO during ARCTAS-A. (b): vertical profiles of $\mathrm{O}_{3}$ during ARCTAS-A. (b): vertical profiles of instantaneous $\mathrm{NP}\left(\mathrm{O}_{3}\right)$ during ARCTAS-A. Similar to Fig. 3, the background air is shown in black and the individual air masses are highlighted in color: stratosphere (purple), stratosphere-troposphere mixed (lilac), anthropogenic pollution (blue), biomass burning (green), and convection/lightning (yellow) (d-f) are the same as (a-c) but for ARCTAS-B.

by stratospheric air show net $\mathrm{O}_{3}$ formation with instan-

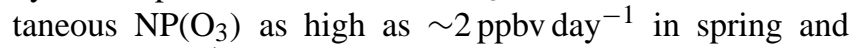
$\sim 5 \mathrm{ppbv}^{-1} \mathrm{day}^{-1}$ in summer. The active photochemical production to some extent offsets the dilution by tropospheric background air which has relatively low $\mathrm{O}_{3}$ and helps in maintaining the high $\mathrm{O}_{3}$ level during STE transport. We are able to calculate the reaction rates offline for Reactions (2), (6), (7), and (8) using observed $\mathrm{O}_{3}$, temperature, and the instantaneous $\mathrm{OH}, \mathrm{HO}_{2}, \mathrm{NO}, \mathrm{O}\left({ }^{1} \mathrm{D}\right)$ calculated by the NASA Langley box model. Figure 12 shows the calculated mean instantaneous rates for these reactions in the stratospheric air and stratosphere-troposphere mixed air, in contrast to the background between $6-12 \mathrm{~km}$. As stratospheric air is entrained into the troposphere during STE, it mixes with the surrounding moist background air, therefore increasing $\mathrm{HO}_{\mathrm{x}}$ through increasing $\mathrm{K}_{6}\left[\mathrm{O}\left({ }^{1} \mathrm{D}\right)\right]\left[\mathrm{H}_{2} \mathrm{O}\right]$ (e.g., Esler et al., 2001). This increases ozone production by increasing $\mathrm{K}_{2}\left[\mathrm{HO}_{2}\right][\mathrm{NO}]$, but at the same time increases ozone loss through increasing $\mathrm{K}_{7}\left[\mathrm{HO}_{2}\right]\left[\mathrm{O}_{3}\right]+\mathrm{K}_{8}[\mathrm{OH}]\left[\mathrm{O}_{3}\right]$. Note that although ozone loss through Reaction $(6)\left(\mathrm{K}_{6}\left[\mathrm{O}\left({ }^{1} \mathrm{D}\right)\right]\left[\mathrm{H}_{2} \mathrm{O}\right]\right)$ also increases significantly, particularly in summer, its rate is much smaller than those of Reactions (2), (7), and (8). The increase in the $\mathrm{O}_{3}$ production term outweighs the loss terms and results in an increase in $\mathrm{NP}\left(\mathrm{O}_{3}\right)$ from near zero to net $\mathrm{O}_{3}$ formation.

Convection/lightning is an important source of $\mathrm{O}_{3}$ during ARCTAS-B. The summertime convective/lightning air mass is elevated in $\mathrm{O}_{3}\left(\Delta \mathrm{O}_{3} \sim 10 \mathrm{ppbv}\right.$, Table $\left.3 \mathrm{~b}\right)$ and displays high net $\mathrm{O}_{3}$ production. This $\mathrm{O}_{3}$ enhancement value is similar to that measured in the convective/lightning air masses $\left(\Delta \mathrm{O}_{3} \sim 5 \mathrm{ppbv}\right)$ during the Intercontinental Chemical Transport Experiment-Phase A (INTEX-A) mission in North America during summer 2004 (Liang et al., 2007). The anthropogenic air mass in general contains relatively low $\mathrm{NO}_{\mathrm{x}}$ (Figs. 4 and 5) and therefore weaker $\mathrm{O}_{3}$ production (Fig. 11). Despite the positive $\mathrm{NP}\left(\mathrm{O}_{3}\right)$ rates, the anthropogenic air mass sampled during both ARCTAS-A and ARCTAS-B show no elevated $\mathrm{O}_{3}$, compared to the background, throughout most of the troposphere. The springtime biomass burning air mass shows active $\mathrm{O}_{3}$ production (mean instantaneous $\mathrm{NP}\left(\mathrm{O}_{3}\right) \sim 2$ ppbv day ${ }^{-1}$ and $\left.\Delta \mathrm{O}_{3} / \Delta \mathrm{CO}=0.22\right)$ and an average $\Delta \mathrm{O}_{3}$ of $16 \mathrm{ppbv}$. The majority of these plumes are aged agricultural biomass burning plumes from Siberia (Fisher et al., 2010). These values are comparable to those reported in the biomass burning plumes in East Asia during the Transport and Chemical Evolution over the Pacific (TRACE-P) 

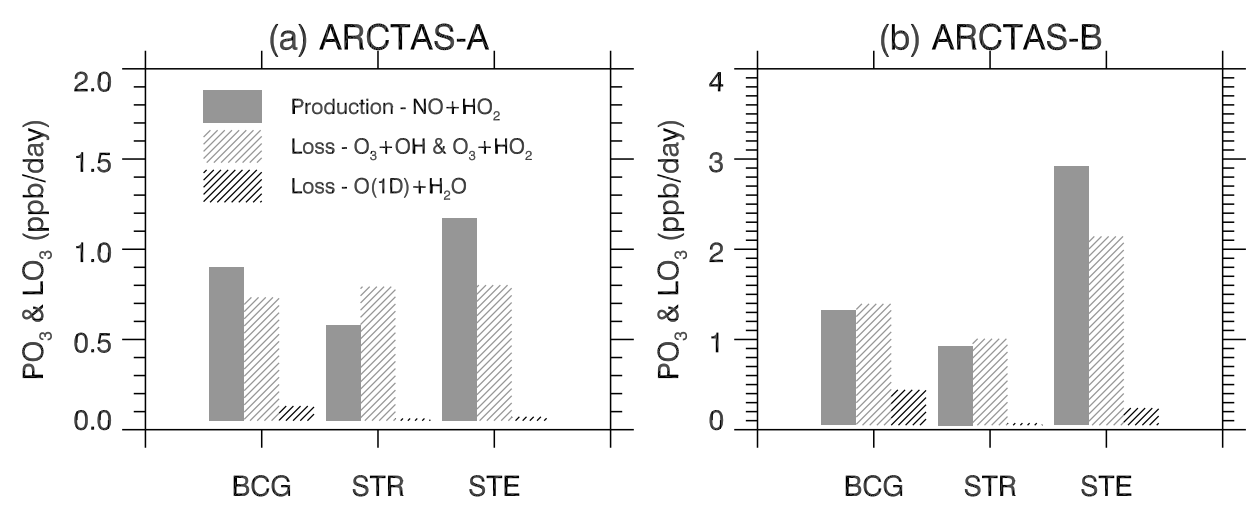

Fig. 12. The mean instantaneous rates of $\mathrm{K}_{2}\left[\mathrm{HO}_{2}\right][\mathrm{NO}], \mathrm{K}_{6}\left[\mathrm{H}_{2} \mathrm{O}\right]\left[\mathrm{O}\left({ }^{1} \mathrm{D}\right)\right]$ and $\mathrm{K}_{7}\left[\mathrm{HO}_{2}\right]\left[\mathrm{O}_{3}\right]+\mathrm{K}_{8}[\mathrm{OH}]\left[\mathrm{O}_{3}\right]$ within the three types of air masses sampled between 6-12 km during ARCTAS: background (BCG), stratospheric air (STR), stratosphere-troposphere mixed air (STE). These instantaneous rates are calculated offline based on the observed $\mathrm{O}_{3}$, temperature, and the instantaneous $\left.\mathrm{OH}, \mathrm{HO} \mathrm{N}_{2}, \mathrm{NO}, \mathrm{O}^{1} \mathrm{D}\right)$ calculated by the NASA Langley box model.

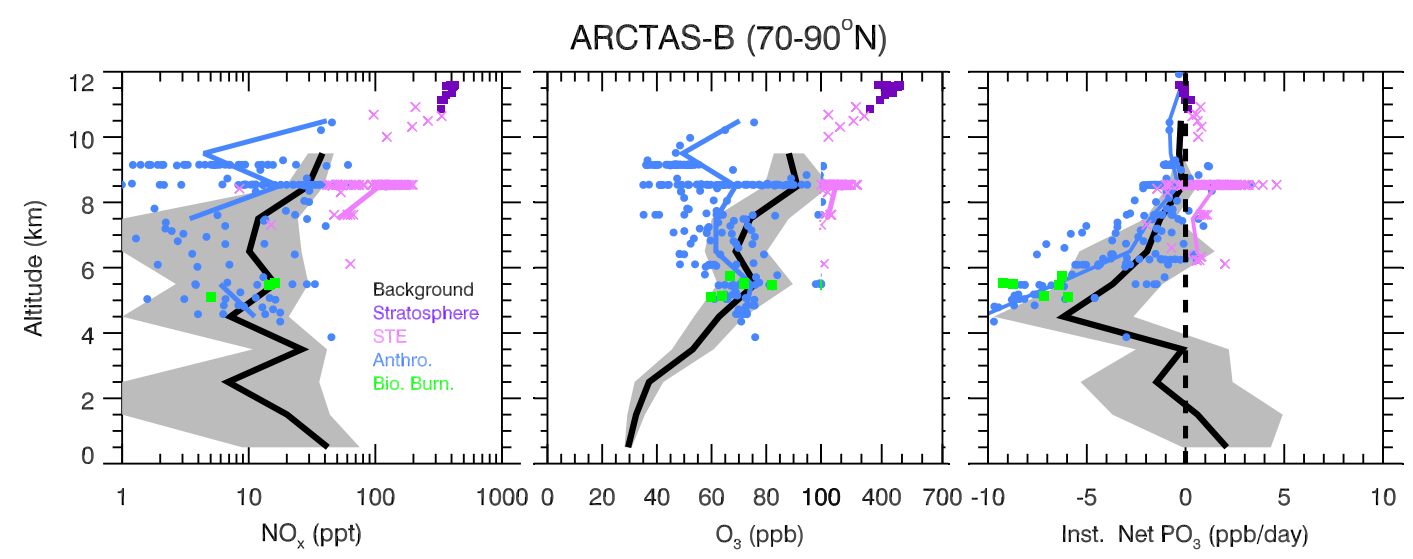

Fig. 13. Vertical profiles of (a) $\mathrm{NO}_{\mathrm{x}}$, (b) $\mathrm{O}_{3}$, and (c) instantaneous $\mathrm{NP}\left(\mathrm{O}_{3}\right)$ between $70^{\circ} \mathrm{N}-90^{\circ} \mathrm{N}$ during ARCTAS-B. Similar to Fig. 10, the background air is shown in black with individual air masses highlighted in color: stratosphere (purple), stratosphere-troposphere mixed (lilac), anthropogenic pollution (blue), biomass burning (green).

mission ( $\Delta \mathrm{O}_{3} \sim 2-15 \mathrm{ppb}$ ) (Tang et al., 2003), the contribution of Indonesia biomass burning calculated by Duncan et al. (2003) $\left(\Delta \mathrm{O}_{3} \sim 10-20 \mathrm{ppb}\right)$ as well as the $\Delta \mathrm{O}_{3} / \Delta \mathrm{CO}$ ratio in the North American boreal fire plumes during INTEXA $\left(\Delta \mathrm{O}_{3} / \Delta \mathrm{CO}=0.25\right)$ (Pfister et al., 2006). The $\Delta \mathrm{O}_{3} / \Delta \mathrm{CO}$ in the aged biomass burning plumes sampled in the equatorial Atlantic during fall 1992 were significantly higher, with mean $\Delta \mathrm{O}_{3} / \Delta \mathrm{CO}=0.7$ (Mauzerall et al., 1998). In contrast, biomass burning air masses sampled in summer, although showing very high positive $\mathrm{NP}\left(\mathrm{O}_{3}\right)$ values, display no elevated $\mathrm{O}_{3}$. Alvarado et al. (2010) conducted a detailed analysis of $\mathrm{NO}_{\mathrm{x}}$ and PAN photochemistry in fresh boreal fire plumes during ARCTAS-B and their impact on $\mathrm{O}_{3}$ and found little evidence of $\mathrm{O}_{3}$ formation in the smoke plumes in the aircraft, satellite, or model results, in accordance with our findings. Paris et al. (2009) also found negative $\mathrm{O}_{3} / \mathrm{CO}$ ratio $\left(-0.04 \mathrm{ppbv} \mathrm{ppbv}^{-1}\right)$, indicating photochemical destruction of $\mathrm{O}_{3}$ in the summertime Siberian fire plumes observed during the YAK-AEROSIB/POLARCAT experiment. While the
$\mathrm{NP}\left(\mathrm{O}_{3}\right)$ in the summer fire plumes are high, this high production is not sustainable as $\mathrm{O}_{3}$ production efficiency is low and $\mathrm{NO}_{\mathrm{x}}$ are rapidly converted to PAN in $\sim 2 \mathrm{~h}$ (Alvarado et al., 2010). However, a study by Real et al. (2007) demonstrated that thermal decomposition of PAN in a biomass burning plume can lead to a $17 \mathrm{ppbv}$ increase of $\mathrm{O}_{3}$ in 5 days during its long-range transport from Alaska to Europe.

As we have discussed in Sect. 3.1, measurements obtained during ARCTAS-B are concentrated in the sub-Arctic between $50^{\circ} \mathrm{N}-70^{\circ} \mathrm{N}$. Our conclusions may not represent the true Arctic troposphere as more convection occurs in the continental sub-Arctic and is closer to pollution sources. We narrow our investigation to focus only on the measurements obtained north of $70^{\circ} \mathrm{N}$ during ARCTAS-B (Fig. 13). While there is a significant fraction of convection/lightning air masses identified during ARCTAS-B, none is sampled in the deep Arctic. Air masses associated with STE events are the only notable contributors to $\mathrm{NO}_{\mathrm{x}}$ and $\mathrm{O}_{3}$ north of $70^{\circ} \mathrm{N}$. In addition, the stratosphere-troposphere mixed air mass is 
the only air mass that displays net $\mathrm{O}_{3}$ formation above $2 \mathrm{~km}$. The mean 24-h averaged $\mathrm{NP}\left(\mathrm{O}_{3}\right)$ (calculated by the Langley box model) in the fresh stratosphere-troposphere mixed air mass sampled during ARCTAS-B is $\sim 0.9 \mathrm{ppbv}^{\text {day }}{ }^{-1}$. These findings confirm our previous proposition that STE, in addition to its direct contribution to $\mathrm{O}_{3}$, is the driving mechanism of net $\mathrm{O}_{3}$ formation in the Arctic upper troposphere as calculated in the GMI Combo CTM (0-10 ppbv month ${ }^{-1}$ in July) (Liang et al., 2009).

\section{Conclusions}

The NASA ARCTAS mission presents a unique opportunity with its extensive suite of measurements to examine $\mathrm{O}_{3}$ photochemistry in the Arctic troposphere. The PDF distribution of the observed CO suggests that the DC- 8 aircraft measurements obtained during spring (ARCTAS-A) are representative of the mean Arctic troposphere. Measurements obtained during the summer deployment (ARCTAS-B) are highly biased towards pollution plumes, a fact to consider in understanding the mean chemical composition of the summertime Arctic troposphere and the impact of pollution plumes.

We conducted a detailed analysis to examine $\mathrm{O}_{3}$ and $\mathrm{NO}_{y}$ in the Arctic and sub-Arctic region and their source attribution. Using a number of marker tracers, we were able to identify various air masses from the background, including anthropogenic pollution, biomass burning emissions, air masses associated with fresh stratosphere-troposphere exchange, and convection and/or lightning influences.

The background Arctic troposphere has mean $\mathrm{O}_{3}$ of $\sim 60$ ppbv and $\mathrm{NO}_{\mathrm{x}}$ of $\sim 25$ pptv throughout spring and summer. The mean CO mixing ratio decreases from $\sim 145 \mathrm{ppbv}$ during spring to $\sim 100 \mathrm{ppbv}$ in summer. The Arctic troposphere is in the $\mathrm{NO}_{\mathrm{x}}$-limited regime with much of the free troposphere showing net $\mathrm{O}_{3}$ destruction due to its low $\mathrm{NO}_{\mathrm{x}}$ concentration. These observed $\mathrm{CO}, \mathrm{NO}_{\mathrm{x}}$ and $\mathrm{O}_{3}$ mixing ratios are not notably different from the values measured during the 1988 ABLE-3A and the 2002 TOPSE field campaigns.

Air masses associated with recent stratospheretroposphere exchange are present at $>5 \mathrm{~km}$ during spring and summer. These air masses with mean $\mathrm{O}_{3}$ concentrations of $140-160 \mathrm{ppbv}$ are significant direct sources of $\mathrm{O}_{3}$ in the Arctic $\left(>70^{\circ} \mathrm{N}\right)$ troposphere. Air of stratospheric origin is also significantly elevated in $\mathrm{NO}_{\mathrm{x}}$ (mean $\sim 75 \mathrm{pptv}$ in spring and 110 pptv in summer) and $\mathrm{HNO}_{3}$ (mean $\sim 290$ pptv in spring and 500 pptv in summer), which will further release $\mathrm{NO}_{\mathrm{x}}$ through photochemical destruction. Driven by high $\mathrm{NO}_{\mathrm{x}}$, these air masses display active net $\mathrm{O}_{3}$ formation with instantaneous production rates as high as $\sim 2 \mathrm{ppbv} \mathrm{day}^{-1}$ in spring and $\sim 5 \mathrm{ppbv} \mathrm{day}^{-1}$ in summer. During ARCTAS-B, several plumes that were influence by stratospheric air also show conversion of $\mathrm{HNO}_{3}$ to PAN. This active production of PAN is the result of increased degradation of ethane in the stratosphere-troposphere mixed air to form $\mathrm{CH}_{3} \mathrm{CHO}$, followed by subsequent formation of PAN under high $\mathrm{NO}_{\mathrm{x}}$ conditions. This implies that the impact of $\mathrm{NO}_{\mathrm{y}}$-enriched stratospheric air on tropospheric $\mathrm{NO}_{\mathrm{x}}$, and therefore $\mathrm{O}_{3}$ production, can be extended much further as the resulting PAN is transported to the lower altitudes and releases $\mathrm{NO}_{\mathrm{x}}$ downwind through thermal decomposition (e.g., Moxim et al., 1996; Honrath et al., 1996). Although a quantitative estimate of the impact of the influx of $\mathrm{NO}_{y}$ from the stratosphere on tropospheric $\mathrm{NO}_{\mathrm{x}}$, PAN, and, subsequently, $\mathrm{O}_{3}$ production is yet to be determined through more comprehensive 3-dimensional global chemistry modeling studies, the findings from the ARCTAS measurements suggest that an accurate representation of this influx, in addition to stratospheric influx of $\mathrm{O}_{3}$, is essential in tropospheric chemistry transport models of the Arctic to accurately simulate $\mathrm{O}_{3}, \mathrm{NO}_{\mathrm{x}}$, and PAN in the Arctic troposphere.

Although anthropogenic and biomass burning pollution plumes show highly elevated hydrocarbons and $\mathrm{NO}_{\mathrm{y}}$ (mostly in the form of $\mathrm{NO}_{\mathrm{x}}$ and PAN). Except some aged Siberia biomass burning plumes during spring, the majority of the pollution plumes has $\mathrm{O}_{3}$ levels comparable to that in the Arctic troposphere, and thus unlikely to further increase the background $\mathrm{O}_{3}$. However, it is important to point out that anthropogenic and biomass burning emissions can still exert an impact on $\mathrm{O}_{3}$ in the Arctic through increasing the background $\mathrm{O}_{3}$ in the mid-latitudes which then enters the polar troposphere through long-range transport, as demonstrated by Shindell et al. (2008). Convection and/or lightning influences are of negligible importance as a source of $\mathrm{O}_{3}$ in the Arctic but can have significant impacts in the upper troposphere in the continental sub-Arctic during summer.

\section{Supplementary material related to this article is available online at: http://www.atmos-chem-phys.net/11/13181/2011/ acp-11-13181-2011-supplement.pdf.}

Acknowledgements. The authors thank R. C. Cohen for providing nitrates measurements. This research was supported by the NASA ARCTAS and MAP programs. Part of the funding for this study is from the NNH08ZDA001N project supported by the MAP program. $\mathrm{CH}_{3} \mathrm{CN}$ measurements were supported by the Austrian Research Promotion Agency (FFG-ALR) and the Tiroler ukunftsstiftung, and were carried out with the help/support of T. Mikoviny, M. Graus, A. Hansel and T. D. Maerk.

Edited by: K. Law 


\section{References}

Allen, D. J., Dibb, J. E., Ridley, B., Pickering, K. E., and Talbot, R.W.: An estimate of the stratospheric contribution to springtime tropospheric ozone maxima using TOPSE measurements and beryllium-7 simulations, J. Geophys. Res., 108, 8355, doi:10.1029/2001JD001428, 2003.

Alvarado, M. J., Logan, J. A., Mao, J., Apel, E., Riemer, D., Blake, D., Cohen, R. C., Min, K.-E., Perring, A. E., Browne, E. C., Wooldridge, P. J., Diskin, G. S., Sachse, G. W., Fuelberg, H., Sessions, W. R., Harrigan, D. L., Huey, G., Liao, J., Case-Hanks, A., Jimenez, J. L., Cubison, M. J., Vay, S. A., Weinheimer, A. J., Knapp, D. J., Montzka, D. D., Flocke, F. M., Pollack, I. B., Wennberg, P. O., Kurten, A., Crounse, J., Clair, J. M. St., Wisthaler, A., Mikoviny, T., Yantosca, R. M., Carouge, C. C., and Le Sager, P.: Nitrogen oxides and PAN in plumes from boreal fires during ARCTAS-B and their impact on ozone: an integrated analysis of aircraft and satellite observations, Atmos. Chem. Phys., 10, 9739-9760, doi:10.5194/acp-10-9739-2010, 2010.

Apel, E. C, Hills, A. J., Lueb, R., Zindel, S., Eisele, S., and Riemer, D. D.: A fast-GC/MS system to measure C-2 to C-4 carbonyls and methanol aboard aircraft, J. Geophys. Res., 108, 8794, doi:10.1029/2002JD003199, 2003.

Atlas, E. L., Ridley, B. A., and Cantrell, C. A.: The Tropospheric Ozone Production about the Spring Equinox (TOPSE) Experiment: Introduction, J. Geophys. Res., 108, 8353, doi:10.1029/2002JD003172, 2003.

Beine, H. J., Jaffe, D. A., Herring, J. A., Kelley, J. A., Krognes, T., and Stordal, F.: High-Latitude Springtime Photochemistry. Part I: $\mathrm{NO}_{\mathrm{x}}$, PAN and Ozone Relationships, J. Atmos. Chem., 27, 127-153, 1997.

Blake, N. J., Blake, D. R., Simpson, I. J., Meinardi, S., Swanson, A. L., Lopez, J. P., Katzenstein, A. S., Barletta, B., Shirai, T., Atlas, E., Sachse, G., Avery, M., Vay., S., Fuelberg, H. E., Kiley, C. M., Kita, K., and Rowland, F. S.: NMHCs and halocarbons in Asian continental outflow during the Transport and Chemical Evolution over the Pacific (TRACE-P) field campaign: comparison with PEM-West B, J. Geophys. Res., 108, 8806, doi:10.1029/2002JD003367, 2003.

Brune, W. H., Tan, D., Faloona, I. F., Jaeglé, L., Jacob, D. J., Heikes, B. G., Snow, J., Kondo, Y., Shetter, R., Sachse, G. W., Anderson, B., Gregory, G. L., Vay, S., Singh, H. B., Davis, D. D., Crawford, J. H., and Blake, D. R.: $\mathrm{OH}$ and $\mathrm{HO}_{2}$ chemistry in the North Atlantic free troposphere, Geophys. Res. Lett., 26, 3077-3080, 1999.

Cleary, P. A., Wooldridge, P. J., and Cohen, R. C.: Laser-induced fluorescence detection of atmospheric $\mathrm{NO}_{2}$ using a commercial diode laser and a supersonic expansion, Appl. Opt., 41, 69506956, 2002.

Crounse, J., McKinney, K. A., Kwan, A. J., and Wennberg, P. O.: Measurement of gas-phase hydroperoxides by chemical ionization mass spectrometry, Anal. Chem., 78, 6726-6732, 2006.

Dibb, J. E., Talbot, R. W., Scheuer, E., Seid, G., DeBell, L., Lefer, B., and Ridley, B.: Stratospheric influence on the northern North American free troposphere during TOPSE: 7Be as a stratospheric tracer, J. Geophys. Res., 108, 8363, doi:10.1029/2001JD001347, 2003.

Diskin, G. S., Podolske, J. R., Sachse, G. W., and Slate, T. A.: Open-Path Airborne Tunable Diode Laser Hygrometer, in Diode
Lasers and Applications in Atmospheric Sensing, SPIE Proceedings 4817, edited by: Fried, A., 196-204, 2002.

Duncan, B. N., Bey, I., Chin, M., Mickley, L. J., Fairlie, T. D., Martin, R. V., and Matsueda, H.: Indonesian wildfires of 1997: Impact on tropospheric chemistry, J. Geophys. Res., 108, 4458, doi:10.1029/2002JD003195, 2003.

Esler, J. G., Tan, D. G. H., Haynes, P. H., Evans, M. J., Law, K. S., Plantevin, P.-H., and Pyle, J. A.: Stratosphere-troposphere exchange: Chemical sensitivity to mixing, J. Geophys. Res., 106, 4717-4731, doi:10.1029/2000JD900405, 2001.

Fisher, J. A., Jacob, D. J., Purdy, M. T., Kopacz, M., Le Sager, P., Carouge, C., Holmes, C. D., Yantosca, R. M., Batchelor, R. L., Strong, K., Diskin, G. S., Fuelberg, H. E., Holloway, J. S., Hyer, E. J., McMillan, W. W., Warner, J., Streets, D. G., Zhang, Q., Wang, Y., and Wu, S.: Source attribution and interannual variability of Arctic pollution in spring constrained by aircraft (ARCTAS, ARCPAC) and satellite (AIRS) observations of carbon monoxide, Atmos. Chem. Phys., 10, 977-996, doi:10.5194/acp-10-977-2010, 2010.

Hansen, J., Sato, M., and Ruedy, R.: Radiative forcing and climate response, J. Geophys. Res., 102, 6831-6864, doi:10.1029/96JD03436, 1997.

Harriss, R. C., Wofsy, S. C., Bartlett, D. S., Shipham, M. C., Jacob, D. J., Hoell, J. M., Bendura, R. J., Drewry, J. W., McNeal, R. J., Navarro, R. L., Gidge, R. N., and Babine, V. E.: The Arctic Boundary Layer Expedition (ABLE-3A): July-August 1988, J. Geophys. Res., 97, 16383-16394, 1992.

Holton, J. R., Haynes, P. H., McIntyre, M. E., Douglass, A. R., Rood, R. B., and Pfister, L.: Stratosphere-troposphere exchange, Rev. Geophys., 33, 403-439, 1995.

Holzinger, R., Jordan, A., Hansel, A., and Lindinger, W.: Automobile emissions of acetonitrile: Assessments of its contribution to the global source, Atmos. Environ., 38, 187-193, 2001.

Honrath, R. E., Hamlin, A. J., and Merrill, J. T.: Transport of ozone precursors from the Arctic troposphere to the North Atlantic region, J. Geophys. Res., 101, 29335-29351, 1996.

IPCC Fourth Assessment Report, Climate Change 2007, IPCC, Geneva, Switzerland.

Jacob, D. J.: Introduction to Atmospheric Chemistry, Princeton University Press, p. 240, 1999.

Jacob, D. J., Crawford, J. H., Maring, H., Clarke, A. D., Dibb, J. E., Emmons, L. K., Ferrare, R. A., Hostetler, C. A., Russell, P. B., Singh, H. B., Thompson, A. M., Shaw, G. E., McCauley, E., Pederson, J. R., and Fisher, J. A.: The Arctic Research of the Composition of the Troposphere from Aircraft and Satellites (ARCTAS) mission: design, execution, and first results, Atmos. Chem Phys., 10, 5191-5212, doi:10.5194/acp-10-5191-2010, 2010.

Jacob, D. J., Wofsy, S. C., Bakwin, P. S., Fan, S.-M., Harriss, R. C., Talbot, R. W., Bradshaw, J. D., Sandholm, S. T., Singh, H. B., Browell, E. V., Gregory, G. L., Sachse, G. W., Shipham, M. C., Blake, D. R., and Fitzjarrald, D. R.: Summertime photochemistry at high northern latitudes, J. Geophys. Res., 97, 1642116431, 1992.

Jaeglé, L., Jacob, D. J., Brune, W. H., Tan, D., Faloona, I. C., Weinheimer, A. J., Ridley, B. A., Campos, T. L., and Sachse, G. W.: Sources of $\mathrm{HO}_{\mathrm{x}}$ and production of ozone in the upper troposphere over the United States, Geophys. Res. Lett., 25, 17091712, 1998.

Klonecki, A. A. and Hevy II, H.: Tropospheric chemical ozone ten- 
dencies in the $\mathrm{CO}-\mathrm{CH}_{4}-\mathrm{NO}_{\mathrm{y}}-\mathrm{H}_{2} \mathrm{O}$ system: Their sensitivity to variations in environmental parameters and their application to a GCTM study, J. Geophys. Res., 102, 21221-21237, 1997.

Law, K. S. and Stohl, A.: Arctic Air Pollution: Origins and Impacts, Science, 315, 1537, doi:10.1126/science.1137695, 2007.

Levy II, H., Moxim, W. J., Klonecki, A. A., and Kasibhatla, P. S.: Simulated tropospheric NOx: Its evaluation, global distribution and individual source contributions, J. Geophys. Res., 104, 26279-26306, 1999.

Liang, Q., Jaeglé, L., Hudman, R. C., Turquety, S., Jacob, D. J., Avery, M. A., Browell, E. V., Sachse, G. W., Blake, D. R., Brune, W., Ren, X., Cohen, R. C., Fried, A., Fuelberg, H., Porter, M., Heikes, B. G., Huey, G., Singh, H. B., and Wennberg, P. O.: Summertime influence of Asian pollution in the free troposphere over North America, J. Geophys. Res., 112, D12S11, doi:10.1029/2006JD007919, 2007.

Liang, Q., Stolarski, R. S., Douglass, A. R., Newman, P. A., and Nielsen, J. E.: Evaluation of emissions and transport of CFCs using surface observations and their seasonal cycles and the GEOS CCM simulation with emissions-based forcing, J. Geophys. Res., 113, D14302, doi:10.1029/2007JD009617, 2008.

Liang, Q., Douglass, A. R., Duncan, B. N., Stolarski, R. S., and Witte, J. C.: The governing processes and timescales of stratosphere-to-troposphere transport and its contribution to ozone in the Arctic troposphere, Atmos. Chem. Phys., 9, 30113025, doi:10.5194/acp-9-3011-2009, 2009.

Lin, X., Trainer, M., and Liu, S. C.: On the nonlinearity of the tropospheric ozone production, J. Geophys. Res., 93, 15879-15888, 1988.

Lobert, J. M., Scharffe, D. H., Hao, W. M., and Crutzen, P. J.: Importance of biomass burning in the atmospheric budgets of nitrogen-containing gases, Nature, 346, 552-554, 1990.

Mauzerall, D. L, Logan, J. A., Jacob, D. J., Anderson, B. E., Blake, D. R., Bradshaw, J. D., Heikes, B., Sachse, G. W., Singh, S., and Talbot, R.: Photochemistry in biomass burning plumes and implications for tropospheric ozone over the tropical South Atlantic, J. Geophys. Res., 103, 8401-8423, 1998.

Moxim, W. J., Levy, H., and Kasibhalta, P. S.: Simulated global tropopsheric PAN: its transport and impact on $\mathrm{NO}_{\mathrm{x}}, \mathrm{J}$. Geophys. Res., 101, 12621-12638, 1996.

Neuman, J. A., Nowak, J. B., Huey, L. G., Burkholder, J. B., Dibb, J. E., Holloway, J. S., Liao, J., Peischl, J., Roberts, J. M., Ryerson, T. B., Scheuer, E., Stark, H., Stickel, R. E., Tanner, D. J., and Weinheimer, A.: Bromine measurements in ozone depleted air over the Arctic Ocean, Atmos. Chem. Phys., 10, 6503-6514, doi:10.5194/acp-10-6503-2010, 2010.

Olson, J. R., Crawford, J. H., Chen, G., Fried, A., Evans, M. J., Jordan, C. E., Sandholm, S. T., Davis, D. D., Anderson, B. E., Avery, M. A., Barrick, J. D., Blake, D. R., Brune, W. H., Eisele, F. L., Flocke, F., Harder, H., Jacob, D. J., Kondo, Y., Lefer, B. L., Martinez, M., Mauldin, R. L., Sachse, G. W., Shetter, R. E., Singh, H. B., Talbot, R. W., and Tan, D.: Testing fast phototochemical theory during TRACE-P based on measurements of $\mathrm{OH}, \mathrm{HO}_{2}$, and $\mathrm{CH}_{2} \mathrm{O}$,J. Geophys. Res., 109, D15S10, doi:10.1029/2003JD004278, 2004.

Paris, J.-D., Stohl, A., Ndlec, P., Arshinov, M. Yu., Panchenko, M. V., Shmargunov, V. P., Law, K. S., Belan, B. D., and Ciais, P.: Wildfire smoke in the Siberian Arctic in summer: source characterization and plume evolution from airborne measurements, At- mos. Chem. Phys., 9, 9315-9327, doi:10.5194/acp-9-9315-2009, 2009.

Parrish, D. D., Trainer, M., Holloway, J. S., Yee, J. E., Warshawsky, M. D., and Fehsenfeld, F. C.: Relationships between ozone and carbon monoxide at surface sites in the North Atlantic region, J. Geophys. Res., 103, D11, doi:10.1029/98JD00376, 1998.

Penkett, S. A. and Brice, K. A.: The spring maximum in photo oxidants in northern-hemisphere troposphere, Nature, 319, 655657, 1986.

Quinn, P. K., Bates, T. S., Baum, E., Doubleday, N., Fiore, A. M., Flanner, M., Fridlind, A., Garrett, T. J., Koch, D., Menon, S., Shindell, D., Stohl, A., and Warren, S. G.: Short-lived pollutants in the Arctic: their climate impact and possible mitigation strategies, Atmos. Chem. Phys., 8, 1723-1735, doi:10.5194/acp8-1723-2008, 2008

Real, E., Law, K. S., Weinzierl, B., Fiebig, M., Petzold, A., Wild, O., Methven, J., Arnold, S., Stohl, A., Huntrieser, H., Roiger, A., Schlager, H., Stewart, D., Avery, M., Sachse, G., Browell, E., Ferrare, R., and Blake, D.: Processes influencing ozone levels in Alaskan forest fire plumes during long-range transport over the North Atlantic, J. Geophys. Res., 112, D10S41, doi:10.1029/2006JD007576, 2007.

Singh, H. B., O'Hara, D., Herlth, D., Bradshaw, J. D., Sandholm, S. T., Gregory, G. L., Sachse, G. W., Blake, D. R., Crutzen, P. J., and Kanakidou, M. A.: Atmospheric measurements of peroxyacetyl nitrate and other organic nitrates at high latitudes: Possible sources and sinks, J. Geophys. Res., 97, 16511-16522, 1992.

Singh, H. B., Anderson, B. E., Brune, W. H., Cai, C., Cohen, R. C., Crawford, J. H., Cubison, M. J., Czech, E. P., Emmons, L., Fuelberg, H. E., Huey, G., Jacob, D. J., Jimenez, J. L., Kaduwela, A., Kondo, Y., Mao, J., Olson, J. R., Sachse, G. W., Vay, S. A., Weinheimer, A., Wennberg, P. O., and Wisthaler, A.: the ARCTAS Science Team: Pollution influences on atmospheric composition and chemistry at high northern latitudes: Boreal and California forest fire emissions, Atmos. Environ., 44, 4553-4564, 2010.

Shindell, D.: Local and remote contributions to Arctic warming, Geophys. Res. Lett., 34, L14704, doi:10.1029/2007GL030221, 2007.

Shindell, D., Faluvegi, F., Lacis, A., Hansen, J., Ruedy, R., and Aguilar, E.: Role of tropospheric ozone increases in 20th-century climate change, J. Geophys. Res., 111, D08302, doi:10.1029/2005JD006348, 2006.

Shindell, D. T., Chin, M., Dentener, F., Doherty, R. M., Faluvegi, G., Fiore, A. M., Hess, P., Koch, D. M., MacKenzie, I. A., Sanderson, M. G., Schultz, M. G., Schulz, M., Stevenson, D. S., Teich, H., Textor, C., Wild, O., Bergmann, D. J., Bey, I., Bian, H., Cuvelier, C., Duncan, B. N., Folberth, G., Horowitz, L. W., Jonson, J., Kaminski, J. W., Marmer, E., Park, R., Pringle, K. J., Schroeder, S., Szopa, S., Takemura, T., Zeng, G., Keating, T. J., and Zuber, A.: A multi-model assessment of pollution transport to the Arctic, Atmos. Chem. Phys., 8, 5353-5372, doi:10.5194/acp-8-5353-2008, 2008.

Sillman, S., Logan, J. A., and Wofsy, S. C.: The sensitivity of ozone to nitrogen oxides and hydrocarbons in regional ozone episodes, J. Geophys. Res., 95, 1837-1852, 1990.

Slusher, D. L., Huey, L. G., Tanner, D. J., Flocke, F. M., and Roberts, J. M.: A thermal dissociation-chemical ionization mass spectrometry (TD-CIMS) technique for the simultaneous measurement of peroxyacyl nitrates and dinitrogen pentoxide, J. 
Geophys. Res., 109, D19315, doi:10.1029/2004JD004670, 2004. Stroud, C., Madronich, S., Atlas, E., Ridley, B., Flocke, F., Weinheimer, A., Talbot, R., Fried, A, Wert, B., Shetter, R., Lefer, B., Coffey, M, Heikes, B., and Blake, D.: Photochemistry in the arctic free troposphere: NOx budget and the role of odd nitrogen reservoir recycling, Atmos. Environ., 37, 3351-3364, 2003.

Tang, Y., Carmichael, G. R., Woo. J.-H., Thongboonchoo, N., Kurata, G., Uno, I., Streets, D. G., Blake, D. R., Weber, R. J., Talbot, R. W, Kondo, Y., Singh, H. B., and Wang, T.: Influences of biomass burning during the Transport and Chemical Evolution Over the Pacific (TRACE-P) experiment identified by the regional chemical transport model, J. Geophys. Res., 108, 8824, doi:10.1029/2002JD003110, 2003.

Thompson, A. M. M., Sparling, L. C., Kondo, Y., Anderson, B. E., Gregory, G. L., and Sachse, G. W.: Perspectives on NO, NOy, and fine aerosol sources and variability during SONEX, Geophys. Res. Lett., 26, 3073-3076, 1999.

Weinheimer, A. J., Walega, J. G., Ridley, B. A., Gary, B. L., Blake, D. R., Blake, N. J., Rowland, F. S., Sachse, G. W., Anderson, B. E., and Collins, J. E.: Meridional distributions of $\mathrm{NO}_{\mathrm{x}}, \mathrm{NO}_{\mathrm{y}}$, and other species in the lower stratosphere and upper troposphere during AASE II, Geophys. Res. Lett., 21, 2583-2586, 1994.
Wisthaler, A., Hansel, A., Dickerson, R. R., and Crutzen, P. J.: Organic trace gas measurements by PTR-MS during INDOEX 1999, J. Geophys. Res., 107, 8024, doi:10.1029/2001JD000576, 2002.

Wennberg, P. O., Hanisco, T. F., Jaeglé, L., Jacob, D. J., Hintsa, E. J., Lanzendorf, E. J., Anderson, J. G., Gao, R.-S., Keim, E. R., Donnelly, S. G., Del Negro, L. A., Fahey, D. W., KcKeen, S. A., Salawitch, R. J., Webster, C. R., May, R. D., Herman, R. L., Proffitt, M. H., Margitan, J. J., Atlas, E. L., Schauffler, S. M., Flocke, F., McElroy, C. T., and Bui, T. P.: Hydrogen Radicals, Nitrogen Radicals, and the Production of $\mathrm{O}_{3}$ in the Upper Troposphere, Science, 279, 49-53, 1998.

Wofsy, S. C., Sachse, G. W., Gregory, G. L., Blake, D. R., Bradshaw, J. D., Sandholm, S. T., Singh, H. B., Barrick, J. A., Harriss, R. C., Talbot, R. W., Shipham, M. A., Browell, E. V., Jacob, D. J., and Logan, J. A.: Atmospheric chemistry in the Arctic and sub-Arctic: Influence of natural fires, industrial emissions, and stratospheric inputs, J. Geophys. Res., 97, 16731-16746, 1992. 